\title{
Heterotypic $A \beta$ interactions facilitate amyloid assembly and modify amyloid structure
}

Katerina Konstantoulea ${ }^{1,2, \#, ~ P a t r i c i a ~ G u e r r e i r o ~}{ }^{1,2, \#}$, Meine Ramakers ${ }^{1,2}$, Nikolaos Louros ${ }^{1,2}$, Liam Aubrey ${ }^{3}$, Bert Houben ${ }^{1,2}$, Emiel Michiels ${ }^{1,2}$, Matthias De Vleeschouwer ${ }^{1,2}$, Yulia Lampi ${ }^{1,2}$, Luís F. Ribeiro ${ }^{4,5}$, Joris de Wit ${ }^{4}$, Wei-Feng Xue ${ }^{3}$, Joost Schymkowitz ${ }^{1,2,}$ and Frederic Rousseau $^{1,2, *}$

${ }^{1}$ Switch Laboratory, VIB Center for Brain and Disease Research, Herestraat 49, 3000 Leuven, Belgium.

${ }^{2}$ Switch Laboratory, Department of Cellular and Molecular Medicine, KULeuven, Herestraat 49, 3000 Leuven, Belgium.

${ }^{3}$ School of Biosciences, University of Kent, Canterbury, CT2 7NJ, United Kingdom

${ }^{4}$ VIB Center for Brain \& Disease Research, Herestraat 49, 3000 Leuven, Belgium

${ }^{5}$ KU Leuven, Department of Neurosciences, Leuven Brain Institute, Herestraat 49, 3000 Leuven, Belgium

* to whom correspondence should be addressed: joost.schymkowitz@kuleuven.vib.be or frederic.rousseau@kuleuven.vib.be

\# equal contribution 
bioRxiv preprint doi: https://doi.org/10.1101/2021.04 28.441786; this version posted April 30, 2021. The copyright holder for this preprint (which was not certified by peer review) is the author/funder, who has granted bioRxiv a license to display the preprint in perpetuity. It is made available under aCC-BY-NC-ND 4.0 International license.

Konstantoulea, Guerreiro et al

\begin{abstract}
It is still unclear why pathological amyloid deposition initiates in specific brain regions, nor why specific cells or tissues are more susceptible than others. Amyloid deposition is determined by the self-assembly of short protein segments called aggregation-prone regions (APRs) that favour cross- $\beta$ structure. Here we investigated whether $A \beta$ amyloid assembly can be modified by heterotypic interactions between A $\beta$ APRs and short homologous segments in otherwise unrelated human proteins. We identified heterotypic interactions that accelerate $A \beta$ assembly, modify fibril morphology and affect its pattern of deposition in vitro. Moreover, we found that co-expression of these proteins in an $A \beta$ reporter cell line promotes $A \beta$ amyloid aggregation. Importantly, reanalysis of proteomics data of $A \beta$ plaques from $A D$ patients revealed an enrichment in proteins that share homologous sequences to the A $\beta$ APRs, suggesting heterotypic amyloid interactions may occur in patients. Strikingly, we did not find such a bias in plaques from overexpression models in mouse. Based on these data, we propose that heterotypic APR interactions may play a hitherto unrealised role in amyloid-deposition diseases.
\end{abstract}


bioRxiv preprint doi: https://doi.org/10.1101/2021.04.28.441786; this version posted April 30, 2021. The copyright holder for this preprint (which was not certified by peer review) is the author/funder, who has granted bioRxiv a license to display the preprint in perpetuity. It is made available under aCC-BY-NC-ND 4.0 International license.

Konstantoulea, Guerreiro et al

\section{Introduction}

Neurodegenerative amyloid diseases are a diverse group of pathologies that present very different symptoms and progressions in different areas of the brain (Chiti \& Dobson, 2017; Goedert et al, 2017; Walsh \& Selkoe, 2016). Simultaneously these diseases share common hallmarks that remain poorly explained. First, their initiation is characterized by the deposition of particular proteins in specific cells or brain regions (Gan et al, 2018). Second, this process is associated to functional and homeostatic dysregulation of affected cells ultimately resulting in neuronal death (Zaman et al, 2019). Third, from the site of initiation the disease progresses in a stereotypical manner by propagation of amyloid deposition to anatomically connected cells and brain regions with symptoms that match their function (Taylor et al, 2002). Together these properties suggest specific neuronal and regional vulnerability of the brain to the aggregation, propagation and toxicity of particular amyloidogenic proteins (Fu et al, 2018; Muratore et al, 2017). Factors enhancing these vulnerabilities include physiological ageing but also disease-specific familial mutations and population risk factors (Hipp et al, 2019; Silva et al, 2019). This illustrates how neuronal susceptibility is favoured by general (protein) homeostatic ageing but that disease initiation and its effects are highly context dependent. It is still unclear which cellular interactions contribute to the modulation of neuronal susceptibility either by sensitizing or protecting particular neurons or brain regions to aggregation. It is also not known whether amyloid interactions in each of these diseases are purely idiosyncratic or whether cross- $\beta$ amyloid structure also favours canonical modes of interaction that provide generic mechanisms for amyloid gain-of-function.

Amyloid structures from different proteins grown either in vitro or in vivo share a common cross- $\beta$ architecture (Gallardo et al, 2020; Landreh et al, 2016; Lutter et al, 2019; Riek \& Eisenberg, 2016). Structural analysis of disease-associated amyloid structures and their polymorphs revealed that they are not uniformly stable but that some regions dominate the thermodynamic stability of the amyloid (van der Kant et al, 2021). Interestingly stable regions correspond to those previously identified as the amyloid nucleating segments of these proteins (Ganesan et al, 2016; Marshall et al, 2016; Teng \& Eisenberg, 2009; Ventura et al, 2004). These aggregation-prone regions (APRs) consist of short sequence segments, 5- 
bioRxiv preprint doi: https://doi.org/10.1101/2021.04.28.441786; this version posted April 30, 2021. The copyright holder for this preprint (which was not certified by peer review) is the author/funder, who has granted bioRxiv a license to display the preprint in perpetuity. It is made available under aCC-BY-NC-ND 4.0 International license.

Konstantoulea, Guerreiro et al

15 residues in length (Fernandez-Escamilla et al, 2004b; Goldschmidt et al, 2010; Rousseau et $a l, 2006 \mathrm{~b})$ and their thermodynamic stability results from their high propensity to adopt the cross- $\beta$ conformation (Louros et al, 2020; Rousseau et al, 2006a; van der Kant et al., 2021). APRs assemble into stable amyloids both on their own as peptides or in the context of full-length proteins underlining their essential (Ganesan et al., 2016; Marshall et al., 2016) and dominant role (Teng \& Eisenberg, 2009; Ventura et al., 2004). Because of these favourable conformational properties, APRs constitute good protein interaction interfaces favouring amyloid self-assembly, i.e. through their affinity for binding to their own sequence (Krebs et al, 2004; O'Nuallain et al, 2005; O'Nuallain et al, 2004; Vanik et al, 2004; Wetzel, 2006). Recent evidence however suggests that amyloid self-specificity is not absolute and that disease amyloids can engage heterotypic interactions resulting in cross-seeding and coaggregation (Giasson et al, 2003; Konstantoulea et al, 2021; Lutter et al., 2019; Ly et al, 2021; Oskarsson et al, 2015) that are relevant to the pathophysiology of these disease (Colom-Cadena et al, 2013; Gallardo et al., 2020; Pham et al, 2019; Sampson et al, 2020; Vasconcelos et al, 2016). The fact that sequence similarity is apparent in many of these cross-interactions (Konstantoulea et al., 2021) - and especially with APRs - suggests that APRs constitute favoured protein interaction interfaces for heterotypic protein interactions.

Here we investigated the potential of amyloid core APRs to engage in heterotypic amyloid interactions with human proteins that share local sequence homology with amyloid APRs. Next, we evaluated the potential of such interactions to modify the structure and kinetics of assembly of amyloids. In order to do this, we used the Alzheimer beta peptide Aß1-42 as a paradigm as it is a relatively short amyloid peptide sequence the kinetics of which are welldocumented. A $\beta$ harbors two APRs: APR1 encompassing residues (16-21) where several familial AD mutations cluster and APR2 at the C-terminal region (29-end), whose variable length is an important factor in the development of sporadic AD (Fernandez-Escamilla et al., 2004b; Marshall et al., 2016; Vandersteen et al, 2012). Both regions have a high aggregation propensity due to a high hydrophobicity and beta-sheet propensity (Fernandez-Escamilla et al, 2004a) and readily form amyloid-like aggregates by themselves as peptides (de la Paz \& Serrano, 2004). The importance of these APRs for the amyloid formation of $A \beta$ was further demonstrated by a variant form of $A \beta 1-42$ that was designed to suppress both APRs by introducing a single amino acid substitution in each region (Marshall et al., 2016). This 
bioRxiv preprint doi: https://doi.org/10.1101/2021.04.28.441786; this version posted April 30, 2021. The copyright holder for this preprint (which was not certified by peer review) is the author/funder, who has granted bioRxiv a license to display the preprint in perpetuity. It is made available under aCC-BY-NC-ND 4.0 International license.

Konstantoulea, Guerreiro et al

variant, carrying two mutations in total, was shown to no longer aggregate, which also rescued the neurotoxicity of $A \beta$ (Marshall et al., 2016), showing that both APRs are indeed key determinants of the kinetics of amyloid formation of $A \beta$.

We identified several peptides with homology to AB1-42 APR derived from human proteins including proteins expressed in the brain and demonstrated that they are able to interact with $A \beta 1-42$ and alter its aggregation kinetics and fibril morphology. Moreover, we showed that in the context of the full-length protein these same sequences favour $A \beta 1-42$ aggregation in a reporter cell line. Importantly, reanalyzing deep proteomics data of human $A \beta$ plaques (Xiong et al, 2019) we showed that proteins with homology to A $\beta$ APRs are overrepresented in amyloid plaques from $A D$ patients and that they cluster in gene ontologies related to synaptic organization and regulation of vesicle-mediated transport. An overrepresentation that is not seen in mouse APP overexpression models. Together our analysis demonstrates that at least in the case of $A \beta$ amyloid assembly interfaces provided by APRs also allow for heterotypic interactions with other proteins by a mechanism of local sequence homology and that such interactions have the potential to modify amyloid nucleation, elongation and fibril morphology and co-opt such proteins into plaques.

\section{Results}

\section{Nomenclature}

$A \beta$ : The Alzheimer beta-peptide, which exists as a mixture of different length due to carboxy- and amino-terminal heterogeneity resulting from its proteolytic generation.

$A \beta 1-42: A$ single form of the $A \beta$ peptide, starting from canonical position 1 and ending in position 42. This species is particularly enriched in the plaques of patients with sporadic AD.

\section{Mapping $A \beta$ self-interactions using peptide arrays}

To set up a method to investigate self-interactions between $A \beta$ molecules, we turned to a method that was previously successfully used for analysing self-interactions of the yeast prion Sup35 (Tessier \& Lindquist, 2007), namely peptide arrays in which peptides correspond to a sliding window over a target protein. By exposing these arrays to an aggregation-prone protein, the location of self-interaction sites in the sequence can be 
bioRxiv preprint doi: https://doi.org/10.1101/2021.04.28.441786; this version posted April 30, 2021. The copyright holder for this preprint (which was not certified by peer review) is the author/funder, who has granted bioRxiv a license to display the preprint in perpetuity. It is made available under aCC-BY-NC-ND 4.0 International license.

Konstantoulea, Guerreiro et al

observed directly, provided the interacting residues form a contiguous stretch as in the APR model. For this purpose, we synthesised in-house peptide arrays on a cellulose membrane, by using a sliding window scan over the sequence of $A \beta 1-42$ of length 12 and step size 1 (Figure 1a, Appendix Table S1). Given that the most widely used antibodies against $A \beta$ have linear epitopes and thus would show cross-binding on such arrays, we resorted to using a biotinylated derivative of $A \beta 1-42$ (Biot-A $\beta 1-42$, rPeptide) that avoids interference during detection. Upon dissolving Biot-A $\beta 1-42$, we performed Size Exclusion Chromatography (SEC, S75, GE Healthcare) using an inline Multiple Angle Light Scattering detector (MALS, Wyatt) to determine the molecular size of the eluents. This revealed a monomeric peak eluting around $14 \mathrm{~mL}$ and an oligomeric peak, eluting in the void volume (Figure 1b). Then we exposed a peptide array to the monomeric fraction of Biot-A $\beta 1-42$ (100 nM) for 1 hour and detected binding of $A \beta$ to the spotted peptides using streptavidin-HRP, but we observed no significant binding to any of the peptide spots (Figure 1c). However, detection with the 4G8 (Chang et al, 2007), 6E10 and 12F4 antibodies that recognize a central 18-22 epitope in $A \beta$, the $\mathrm{N}$-terminus and the $\mathrm{C}$-terminus respectively showed clearly that these peptide sequences are present, confirming also the quality of synthesis (Appendix Figure S1). When we exposed a fresh membrane to the void volume fraction in the same way as the monomer, we observed clear binding to the N-terminal fraction of APR1 (Figure 1d), but not APR2. We left monomeric Biot-Aß1-42 samples to aggregate (at $10 \mu \mathrm{M}$ ) while monitoring their aggregation kinetics using Thioflavin-T (ThT) fluorescence (Figure 1e). At three different time points during the course of the aggregation, we took samples incubated them in parallel without ThT and put them on a fresh peptide microarray (at $100 \mathrm{nM}$ ). Aggregating species collected during the lag phase of aggregation (sample 1 on Figure 1e) showed again a binding pattern in the amino-terminal peptides of APR1, similar to the void volume species observed during SEC-MALS (Figure 1f). Aggregating species, taken later in the kinetic from the early elongation phase (sample 2), showed binding throughout both APR1 and APR2 (Figure 1g). Finally, the predominantly fibrillar aggregates present during the plateau phase (sample 3), showed only very weak binding to the $A \beta$ peptides (Figure $1 \mathrm{~h}$ ). Finally, we generated amyloid seeds in the reverse reaction, using 15 cycles of 30 s sonication to generate fragments from mature amyloid fibrils that were obtained after 14 days of incubation. We used the aggregation kinetics to confirm that the sonication protocol led to 
bioRxiv preprint doi: https://doi.org/10.1101/2021.04.28.441786; this version posted April 30, 2021. The copyright holder for this preprint (which was not certified by peer review) is the author/funder, who has granted bioRxiv a license to display the preprint in perpetuity. It is made available under aCC-BY-NC-ND 4.0 International license.

Konstantoulea, Guerreiro et al

the formation of functional amyloid seeds, and indeed we found this sample produced a notable reduction of the lag-phase of aggregation of Biot-A $\beta 1-42$ at $5 \%$ or $10 \%$ molar ratio in monomeric units (Figure 1i), whereas the mature fibrils did not have this effect. These 'reverse seeds' (i.e. generated from mature fibrils) indeed also showed an interaction pattern with the membrane that was similar to that of the late oligomers of the elongation phase, with interactions across both APR regions (Figure 1g).

The difference in binding between monomeric and oligomeric Biot-A $\beta 1-42$ species is consistent with the nucleation-growth kinetics of amyloid aggregation, in which the ratelimiting step is the formation of the oligomers, to which monomer addition is then relatively rapid (Dobson, 1999). Hence the preformed oligomers interact much more than the monomer, and the mature fibrils have few interaction sites. Interestingly, the peptide array data also shows that the early Biot-A $\beta 1-42$ oligomeric intermediates (found in the fresh sample or formed from the monomer fraction) engage in different molecular interactions than later oligomeric species, which essentially behave as the fibril fragments generated by sonication. Consistent with the notion that the APRs are the kinetic determinants of $A \beta$ aggregation, we indeed found the oligomers to interact mainly with peptides on the membranes corresponding to these regions. Sequences from APR1 from the central region of $A \beta$ seems to form more interactions with early oligomers, whereas later oligomeric species also interacted with APR2 from the C-terminus.

\section{Protein fragments with local sequence similarity that bind to A $A$ APRs occurs throughout}

\section{the proteome}

The APR regions of $A \beta$ vary in length from 6 to more than 10 amino acids, a size distribution similar to that of APRs in other amyloids. Although most sequences of length 7 amino acids and longer are unique within the human proteome (Ganesan et al, 2015), we wondered how much sequence similarity exist within the proteome when considering mismatches. To this end, we plotted the number of similar sequence matches found in the human proteome (up to 2 mismatches) in function of fragment length, based on 1000 randomly selected human protein fragments per length, allowing up to 2 mismatches (Figure 2a) (proteome obtained from UniProt (UniProt, 2008), reviewed/unreviewed entries, filtered for $90 \%$ redundancy using CD-Hit (Fu et al, 2012)). This plot shows that the number of sequence 
bioRxiv preprint doi: https://doi.org/10.1101/2021.04.28.441786; this version posted April 30, 2021. The copyright holder for this preprint (which was not certified by peer review) is the author/funder, who has granted bioRxiv a license to display the preprint in perpetuity. It is made available under aCC-BY-NC-ND 4.0 International license.

Konstantoulea, Guerreiro et al

matches drops exponentially with the length of the fragment and levels off at a length of 9 amino acid residues. Incidentally, this is the length that the immune system employs for self-discrimination, i.e. the length of the peptides displayed by the Major Histocompatibility complex (MHC) start at 9 amino acids. Given this strong dependence on fragment length of the number of homologous matches found for any given sequence in the proteome, we chose to fix this parameter in order to compare between APRs. Hence, we decided to use a relatively low fragment length of 6 to combine some specificity with a large candidate pool. Thus, we performed a search of the human proteome for hexapeptides matching KLVFFA and LVFFAE, allowing up to two mismatches, yielding 4390 matches, not filtering for isoforms (Appendix Table S2). We chose the middle region APR peptides since in our peptide microarrays showed strong binding with both early and late oligomers. Apart from $A \beta$ and the parental amyloid precursor protein (APP), the only other proteins with an identical match are the Potassium voltage-gated channel subfamily $B$, members 1 and 2, which have a perfect match to LVFFAE towards the extracellular region of a transmembrane region. In addition, we identified 61 matches with a single mutation and 4318 matches with 2 mutations. The composition of the mismatches appears to follow a fairly random distribution (Figure $2 \mathrm{~b}$ and $\mathrm{c}$ ), with most amino acids appearing at each position.

Since for technical reasons the maximum number of sequences we can currently include on our cellulose array format is 600 , we randomly selected this number of fragments from the initial list (Appendix Table S3). We then generated a new membrane with these fragments across the proteome, and to take the immediate sequence context into account, we included $2 \mathrm{~N}$-amino acid and $3 \mathrm{C}$-amino acid flanks from the matching protein. We exposed this membrane to oligomeric Biot-A $\beta 1-42$ coming from the void fraction of SEC (Figure $1 d$ ), and detected the binding pattern to the large membrane using streptavidin-HRP (Figure $2 \mathrm{~d}$ ). This revealed strong binding with some sequences, whereas other showed no or little binding. The binding pattern was reproducible between independently generated replicates of the same membrane and we also generated replicates with the same sequences but in randomized order (Appendix Figure S2). We calculated the overall binders by identifying manually the lowest positive value and calculating its Zscore (named Zcutoff). Every spot with Zscore> Zcutoff in all 8 membranes (at least 2 repeats for 3 randomizations) identified as Biot-A $\beta 1-42$ interactor. This analysis identified 126 consistent binders from this analysis (21\%) that bound consistently to oligomeric Biot-AB1-42 in all 8 membranes (Appendix 
bioRxiv preprint doi: https://doi.org/10.1101/2021.04.28.441786; this version posted April 30, 2021. The copyright holder for this preprint (which was not certified by peer review) is the author/funder, who has granted bioRxiv a license to display the preprint in perpetuity. It is made available under aCC-BY-NC-ND 4.0 International license.

Konstantoulea, Guerreiro et al

Table S4). A summary of the membrane interactions is shown by averaging the binding intensity and standard deviation from 8 membranes (Figure 2e, Appendix Table S4). When we analysed the sequence composition of the bound sequences (Figure 2f), we found that some substitutions were better tolerated than others, eg R in KLVFFA homologues or $L$ in LVFFAE. However, the homologue peptides have single or double mutations to A $\beta$ APRs, which adds a level of complexity in identifying the most favorable mutations.

These experiments show that the presence of specific peptides on the cellulose surface determine where on the membrane oligomeric Biot- $A \beta 1-42$ deposits. To explore this point further, we printed a new membrane in which we spelled the pseudo-words 'PLAK' and 'AD' using peptide spots from the top 50 binders identified in the previous membranes and surrounded them with peptide spots from random sequences from the human proteome that did not share similarity with $A \beta$ sequences (Figure $2 g$ and $h$, Appendix Table S5). This confirmed the observations above, that the binding patterns are consistent. Although a cellulose membrane is a poor two-dimensional representation of what may be occurring in a complex tissue such as the brain, these consistent binding patterns show that $A \beta$ amyloids can engage in heterotypic interactions with homologous fragments of otherwise unrelated proteins.

\section{Heterotypic APR interactions modify A $\beta 1-42$ amyloid formation in solution}

In order to investigate if the interactions that we detected on the cellulose membrane could affect amyloid aggregation of AB1-42 in solution, we generated soluble versions of 32 peptides selected from the membrane (Table 1). We monitored the aggregation kinetics of recombinant $r A \beta 1-42$ by ThT fluorescence in the presence of equal amounts (1:1 molar ratio in monomeric units) of these peptides and compared them to peptide alone (Figure 3a,b,c \& Appendix Figure S3,S4). We quantified these curves by curve fitting in terms of the lag phase of aggregation $\left(T_{\text {lag }}\right)$, the time at which half the aggregation amplitude is reached $\left(T_{1 / 2}\right)$, the total aggregation amplitude (Amp) and the elongation rate $\left(k_{e}\right)$ (Appendix Table S6). We found that most effects occurred in the lag phase, i.e. where mostly oligomers are populated. We found that 6 peptides showed a statistically significant increase in the lag phase, so slowed down the aggregation of $\mathrm{rA} \beta 1-42$ (Figure $3 \mathrm{~d}$ ), whereas 12 peptides 
bioRxiv preprint doi: https://doi.org/10.1101/2021.04.28.441786; this version posted April 30, 2021. The copyright holder for this preprint (which was not certified by peer review) is the author/funder, who has granted bioRxiv a license to display the preprint in perpetuity. It is made available under aCC-BY-NC-ND 4.0 International license.

Konstantoulea, Guerreiro et al

decreased the lag phase, i.e. accelerate $\mathrm{r} A \beta 1-42$ kinetics. In addition, 7 peptides showed significant differences in fluorescence amplitude (Figure 3e).

To investigate the effect of the peptides on the $\mathrm{rA \beta 1}-42$ mature fibrils, we first analysed the morphology of amyloid fibrils formed in presence of peptides using Transmission Electron Microscopy (TEM, Figure 2f, Appendix Figure S5, S6) and compared it to A $\beta$ fibrils in absence of peptides. We analyzed 10 positions and measured the length of at least 100 fully traced fibrils for each grid to ensure as possible objective quantification. Based on the objective quantification of the fibril length in these images, we found 11 peptides that modified the length of the fibrils (Figure $2 \mathrm{~g}$, Appendix Figure S7). Further, we studied the binding to conformationally sensitive amyloid reporter dyes, which alter their emission spectrum depending on the structural detail in the fibril (pFTAA and curcumin, Figures $2 \mathrm{~h} \&$ Appendix Figure S8,S9). Dye binding showed significant differences between rAß1-42 alone and in presence of peptides for 4 peptides by pFTAA and 2 by curcumin, suggesting a change in the amyloid structure formed (Appendix Figure S9,S10). Moreover, to confirm our observations, we performed Atomic Force Microscopy (AFM) of rAß1-42 fibrils with a selected number of peptides, which allows the width and morphology of individual filaments to be precisely measured. Interestingly, four of the peptides induced alterations in the mesoscopic arrangement of the $\mathrm{rA \beta 1}-42$ aggregates as well as the morphologies of individual fibrils (Figure $3 \mathrm{i}$ ). The presence of the peptides resulted in a change in the width distribution of the fibrils compared to $\mathrm{rA \beta 1}-42$ alone. The average width increased in the presence of these peptides, which could suggest that some fibrils are composed of greater number of protofilaments or changed protofilament arrangements compared to $A \beta$ alone. Individual fibril surface envelope reconstructions (Aubrey et al, 2020; Lutter et al, 2020) of wellseparated fibrils observed in the AFM images confirm that the morphological details of individual fibril structures formed in the presence of the peptides are indeed different to the rAß1-42 fibrils formed in the absence of the peptides (Figure 3i), including some fibrils with a higher twist periodic frequency than in the $A \beta$ only sample.

Our data show that peptide fragments of human proteins with local homology to one of the APRs of $r A \beta 1-42$ can modify $A \beta$ aggregation kinetics as well as the fibril morphology, under conditions where the two molecules have ample opportunity to interact. It of course remains to be seen whether these peptides still modify $A \beta$ aggregation kinetics in the context of their full-length proteins. 
bioRxiv preprint doi: https://doi.org/10.1101/2021.04.28.441786; this version posted April 30, 2021. The copyright holder for this preprint (which was not certified by peer review) is the author/funder, who has granted bioRxiv a license to display the preprint in perpetuity. It is made available under aCC-BY-NC-ND 4.0 International license.

Konstantoulea, Guerreiro et al

\section{Proteins containing local homology to $A \beta$ APRs that favour the initiation of $A \beta 1-42$} aggregation in a biosensor cell line

To test the potential effect by full-length proteins on $A \beta 1-42$ aggregation of these heterotypic interactions in complex biological environments, we implemented a simplified model system that allows to investigate the potential of full-length proteins to modulate $A \beta$ aggregation. To that purpose we created a biosensor cell line in HEK293T, in a similar fashion to a previous lines by the Prusiner (Aoyagi et al, 2019) and Diamond labs (Kaufman et al, 2016), that stably expresses a fusion construct between Aß1-42 and mCherry tag at Nterminal (Figure 4a). In untreated cells of this line, diffuse mcherry fluorescence is observed throughout the cytoplasm of $>95 \%$ of the cells. However, when we prepared seeds of rAß142 by sonicating mature amyloid fibrils and added them to the cells by transfection, we observed the appearance of a punctate pattern of the RFP fluorescence (Figure 4b). Automated high content image analysis revealed that the diffuse to punctate transition occurred in a dose-responsive manner (Figure 4c). We also confirmed that the puncta were protein aggregates using Fluorescence Recovery After Photobleaching (FRAP) in a region of increased fluorescence: bleaching of this region resulted in limited recovery supporting that the observed spots were indeed A $\beta 1-42$ aggregates (Figure 4c, Appendix Figure S10).

In order to test if proteins with homologous regions to the A APR segments are capable of inducing $A \beta 1-42$ aggregation in a similar way that seeds did, 10 expression constructs were generate containing each gene of interest as well as a fluorescent reporter (GFP) expressed by an Internal Ribosome Entry Site (IRES) (Figure 4a). This setup allows us to quantify AB1-42 aggregates in cells that are expressing our protein of interest, and compare it directly with non-transfected cells from the same well. The 10 proteins were chosen based on their binding signal in our peptide microarrays, their synthesis potential, and/or their connection to brain or neurodegenerative diseases (Table 2). From those 10 constructs, 8 correspond to the full-length protein and 2 had to be cut slightly due to size limitations of the synthesis method (TWIST bioscience). When we transfected the biosensor cells with these constructs and compared the number of spots per cell in transfected and non-transfected cells, we identified 3 proteins (correspondent to constructs 6,9 and 10) that by simply being overexpressed induced a significant increase of AB1-42 aggregation (Figure 4d\&e). As further controls we ensured that we did not observe induction of puncta in mock 
bioRxiv preprint doi: https://doi.org/10.1101/2021.04.28.441786; this version posted April 30, 2021. The copyright holder for this preprint (which was not certified by peer review) is the author/funder, who has granted bioRxiv a license to display the preprint in perpetuity. It is made available under aCC-BY-NC-ND 4.0 International license.

Konstantoulea, Guerreiro et al

transfected cells (PBS), nor in cells transfected with a control plasmid expressing only GFP. Moreover, FRAP showed that also these spots were $A \beta 1-42$ aggregates since no recovery was observed after bleaching (Figure 4d, Appendix Figure S11).

To test our hypothesis that the effects we observed on Aß1-42 aggregation were due to the presence of the sequence segments that are homologous to A APRs, we synthesized additional constructs in which we deleted 10-60 aa containing the A APR homologues. We tried very short deletions, corresponding to the homologous segment, but we also made larger deletions. The latter is because APRs are typically part of the hydrophobic core of a globular folded domain, and hence there are typically 1-3 other elements of the structure that have been evolutionarily optimized to interact with the APR. Hence, deletion of just the APR promotes 3D domain swapping type of interactions, where the APR in $A \beta$ would interact with the remaining compatible regions in the rest of the domain, which we have previously shown promotes aggregation through that mechanism (Rousseau et al, 2001). Construct 6 expresses 1-600aa of CPT2 protein, containing the peptide P3 from Table 1 that significantly affected the kinetics and morphology of $A \beta 1-42$ aggregation (Figure 3 ) and as a full-length protein increased the aggregation of $A \beta 1-42$ in our biosensor cell line. We design a control construct, $6 \mathrm{Ctrl}$ by removing the homologous region (aa 379-388) and expressed in $A \beta 1-42$ biosensor. The absent of homology significantly decreased $A \beta$ aggregation when compared to initial construct (Figure 4d,f). Moreover, immunofluorescence confirmed that the majority of aggregates exist in cells expressing CPT2 and partially colocalized with A $\beta$ aggregates (Figure 4h). However, that was not the case for the control (Figure 4h). PLA2G6 (Construct 10) showed the most acute increase of $A \beta 1-42$ aggregation in our biosensor. PLA2G6 control, 10Ctrl, made by removing ANK7 domain (aa 349-378). Expression of this control in $A \beta$ biosensor reduced significantly the aggregation of $A \beta 1-42$ (Figure $4 d, g$ ). Indeed, presence of PLA2G6 induced the aggregation of AB1-42 as seen by immunofluorescence. Moreover, PLA2G6 increased signal is observed in A $1-42$ aggregates (Figure4i). This is not observed in control (Figure 4i). Finally, the third protein that induced aggregation of $A \beta 1-42$ is CLCN3 (Construct 9) (Figure4d,e). Two controls, Ctrl1 and Ctrl2, was made by removing a $63 a a$ domain and 20aa respectively. Removal of the homologous region only showed a minor decrease in the aggregation of A $31-42$ (Appendix Figure S12a,b). Moreover, we could not detect CLCN3 in the AB1-42 aggregates by immunofluorescent (Appendix Figure S12c), and we found another homologous region elsewhere in the CLCN3 sequence, further 
bioRxiv preprint doi: https://doi.org/10.1101/2021.04.28.441786; this version posted April 30, 2021. The copyright holder for this preprint (which was not certified by peer review) is the author/funder, who has granted bioRxiv a license to display the preprint in perpetuity. It is made available under aCC-BY-NC-ND 4.0 International license.

Konstantoulea, Guerreiro et al

complicating the analysis. This suggests that the effect of CLCN3 expression on Aß1-42 aggregation that we observed is indirect or only partially resulted from heterotypic amyloid interactions.

\section{Proteins with local sequence homology to $A \beta$ APRs are enriched in human $A \beta$ plaques}

In order to study if proteins containing segments with high sequence similarity to the APR regions of $A \beta 42$ may be enriched in Alzheimer's disease-associated amyloid plaques, we analysed a proteomics dataset of hippocampal amyloid plaques of $A D$ patients generated from Xiong et al (Xiong et al., 2019). This study provides high quality proteomics profiling at unsurpassed depth of amyloid plaques (AP) and, importantly, nearby control tissue, obtained by tag-labelling high-throughput mass spectrometry, which is a highly quantitative method. We searched the proteins identified in amyloid plaques (1125 AP proteins) and adjacent non-plaque regions for segments with sequence homology to $A \beta 42$ in an unbiased manner: We divided the $A \beta$ sequence into hexapeptides using a sliding window approach and searched the proteins for homologous segments, allowing up to two mutations. To identify if some $A \beta$ segments were overrepresented in amyloid plaques, we studied the occurrence of homologous segments to each $A \beta$ region in amyloid plaques and compared to the control region proteins to calculate enrichment values. Our analysis found six hexapeptide segments of $A B$ to be overrepresented in AP proteins, compared to tissue proteins (Figure 5a). Interestingly, those positions are nearly perfectly overlapping with the $A P R$ regions of $A B A P R$, as would be expected if the enrichment had resulted from heterotypic APR-interactions. Two of these hexapeptides reside in the central region, and partially cover the KLVFFA APR, and 4 additional hexapeptides reside in the C-terminal APR. To further test if the observed overrepresentation is caused by biases in the background proteins, or form set-size imbalances between the AP and control sets, we employed random sub-sampling to estimate the distribution of homologous regions in the background (in a so-called bootstrapping approach). We used the proteins identified in the tissue and created 1000 random samples with protein numbers equal to the AP proteins (Figure 5b). In a similar way, we also created 1000 random samples of the same size taken from the whole human proteome and a random plaque sample for each sample (Figure 5c). Both controls showed that the regions identified to be overrepresented in the plaque are residing in the tails or well outside of the random distributions, supporting the notion that the enrichment 
bioRxiv preprint doi: https://doi.org/10.1101/2021.04.28.441786; this version posted April 30, 2021. The copyright holder for this preprint (which was not certified by peer review) is the author/funder, who has granted bioRxiv a license to display the preprint in perpetuity. It is made available under aCC-BY-NC-ND 4.0 International license.

Konstantoulea, Guerreiro et al

did not occur by chance. In fact, the bootstrapping approach suggests there may be more over-represented regions, but we took a conservative approach and only considered regions that withstood all statistical testing.

After we identify the regions that are overrepresented in amyloid plaques, we wondered if the AP proteins containing homologous segments to the A $\beta$ APRs had a higher aggregation propensity than proteins found in the control tissue that also contain homologous segments, but that are not found in the plaques. To do so we used the TANGO algorithm to analyse the protein segments with homology to $A \beta$ regions identified before as overrepresented. Our analysis showed that homologous regions from AP proteins showed a higher aggregation propensity than the ones not found in the plaques, with two regions (GAIIGL and MVGGVV) showing statistically significant differences (Figure 5d). These results suggest that again that heterotypic APR interactions may be involved in the enrichment of these proteins in the plaques.

Because proteins associated with amyloid plaques may be involved in high risk pathways for $A D$, we sought to identify the pathways that proteins with homology to A $\beta$ APRs are involved. The two previous groups of amyloid plaques were searched against Gene Ontology Biological process pathways and the significantly enriched pathways were isolated (Figure $5 e)$. Interestingly, AP proteins with homology to AB APRs were found to play role in "synaptic organization, structure and activity", pathways highly relevant to AD, since synaptic dysfunction is known to play an important role in AD progression. Finally, we wanted to test if a similar occurrence of homologue to $A \beta$ APR proteins exists in other proteomic studies of AP. Indeed, a similar trend is observed in other AP proteomic profiles, with a range of $35-45 \%$ of proteins found in APs to have a sequence homology to A $\beta$ APRs (Figure 5f)

To investigate if a similar overrepresentation is seen in amyloid plaques from non-AD brains and APP/PS1 mouse model, we analysed them in a similar way (Figure $5 \mathrm{~g}, 6 \mathrm{a}$ ). In the case of amyloid plaques from non-AD brains, two of the 6 previously identified regions were found to be overrepresented (Figure $5 \mathrm{~g}, \mathrm{~h}, \mathrm{i}$ ). Since two of the previously identified six positions are found to be overrepresented, we hypothesized that proteins may still be interacting through the other 4 positions but without reaching the high levels observed in AD brains yet. So, we used the AP proteins found in non-AD plaques that have homology to all 6 regions and the other AP proteins to do the enrichment analysis of Gene Ontology biological 
bioRxiv preprint doi: https://doi.org/10.1101/2021.04 28.441786; this version posted April 30, 2021. The copyright holder for this preprint (which was not certified by peer review) is the author/funder, who has granted bioRxiv a license to display the preprint in perpetuity. It is made available under aCC-BY-NC-ND 4.0 International license.

Konstantoulea, Guerreiro et al

processes, like previously. Interestingly, AP homologue proteins of non-AD brains were also found to be involved in synaptic pathways (Figure $5 \mathrm{j}$ ).

Furthermore, we analysed proteomic data of amyloid plaques from APP/PS1 mouse AD model obtained using a similar method as the human amyloid plaques(Xiong et al., 2019). To do so we analysed in a similar way as previously two biological replicates. Remarkably, the overrepresentation of $A \beta$ homologue regions was completely abolished in both replicates (Figure 6a). However, the random distribution identified 2 to 3 positions slightly significantly overrepresented but not in the extend observed in human AD brains (Figure $6 b, c)$. Mouse models usually are overexpressing $A \beta$ which leads to rapid aggregation and deposition compared to the slow process found in humans. So, the lack of overrepresentation in mouse model suggests that self-aggregation in promoted in the mouse model, reducing the opportunity for heterotypic interactions, thereby potentially explaining the differential toxicity that is observed between humans and mouse.

Finally, to test if the observed overrepresentation is exclusively seen in amyloid plaques and not aggregates from other proteins, we sought to analyse proteomic data from other pathological aggregates. We chose to analyse a study of Glial cytoplasmic inclusions (GCls), which are mainly composed from $\alpha$-synuclein, from Multiple system atrophy (MSA) brains (McCormack et al, 2019). These GCls were isolated from Basal Ganglia of 5 MSA brains and the proteins identified in at least 4 cases were used as the aggregation-related proteins. Since, this analysis comes from purification of aggregates, no normal tissue was analysed. To overcome this problem, we used as tissue, proteins identified in a proteomic study of Basal ganglia (Fernandez-Irigoyen et al, 2014). From our analysis, no overrepresentation of any A region was observed in those $\alpha$-synuclein enriched aggregates. This result indicates that the proteins with $A \beta$ homology regions are primarily found in amyloid plaques and are not significantly overrepresented in aggregates driven by other proteins. 
bioRxiv preprint doi: https://doi.org/10.1101/2021.04.28.441786; this version posted April 30, 2021. The copyright holder for this preprint (which was not certified by peer review) is the author/funder, who has granted bioRxiv a license to display the preprint in perpetuity. It is made available under aCC-BY-NC-ND 4.0 International license.

Konstantoulea, Guerreiro et al

\section{Discussion}

Understanding selective neuronal and regional vulnerability requires knowledge of both loss- and gain-of-function effects associated to amyloid deposition. Much of our understanding on the role of amyloids in neurodegenerative diseases derives from improvements in our knowledge of the native function of these proteins. At the same time, it remains hard to contextualize the role of amyloid deposition and in particular the specific interactions they engage and how these contribute to disease. Historically, a lot of the mechanistic thinking on the role of amyloids in disease was inspired by their common structural properties and the presumption that amyloids therefore also possess generic modes of interaction with their environment (Bucciantini et al, 2004; Bucciantini et al, 2002; Campioni et al, 2010; Flagmeier et al, 2020). Yet the overall view that emerged is that of rather promiscuous amyloids that easily interact with various lipids \& membranes or nucleic acids and that co-precipitate in unspecific manner with many other proteins (Olzscha et al, 2011). This view has been complemented by the realization that protein expression of many proteins - and particularly in the brain - leads to their supersaturation (Ciryam et al, 2015; Tartaglia et al, 2007) while proteostatic regulation erodes with ageing (Labbadia \& Morimoto, 2015) together setting the scene of a metastable proteome that becomes increasingly prone to collapse. While these finding have vastly increased our understanding of the existence of misfolding $\&$ aggregation diseases and the conditions favouring their development they do not explain the specific neuronal vulnerabilities characterizing each of these diseases.

We here show that $A \beta$ oligomers can interact with various short APR homologous segments of otherwise unrelated human proteins and that such interactions modify $A \beta$ aggregation kinetics and fibril morphology. Such heterotypic interactions de facto modify the cellular vulnerability of a reporter cell line for spontaneous $A \beta$ aggregation. While this cellular model does not aim to mimic the pathological context of amyloid initiation in Alzheimer's disease it does in a simplified manner illustrate how cellular vulnerability for amyloid initiation can be shaped by specific interactions of a disease amyloid with its proteomic background. While the cross- $\beta$ propensity of APRs favours self-assembly it also allows some degree of 'off target' interaction which can further facilitate or inhibit amyloid assembly 
bioRxiv preprint doi: https://doi.org/10.1101/2021.04.28.441786; this version posted April 30, 2021. The copyright holder for this preprint (which was not certified by peer review) is the author/funder, who has granted bioRxiv a license to display the preprint in perpetuity. It is made available under aCC-BY-NC-ND 4.0 International license.

Konstantoulea, Guerreiro et al

thereby sensitizing or protecting cells from amyloid nucleation. Our findings are supported by the increasing observation of heterotypic amyloid assembly both in disease and for the functional regulation of biological processes (Louros et al, 2016; Zhou et al, 2012). These experiments have further revealed the importance of local sequence homology in heterotypic amyloid assembly, indicating that the selectivity of these interactions is related to the sequence similarity level shared between constituent elements (Kehrloesser et al, 2016; O'Nuallain et al., 2004; van der Kant et al., 2021; Wang \& Fersht, 2015; Xu et al, 2011; Yan et al, 2007). Co-assembly often results in accelerated and more severe pathological outcomes, as reported for A $\beta$ and $\alpha$-synuclein in AD and PD patients (Mandal et al, 2006). Both proteins have been shown to hold a nucleation effect towards Tau (Colom-Cadena et al., 2013), whereas huntingtin may as well be involved in cross-fibrillation mechanisms, leading to polyglutamine disorders (Furukawa et al, 2009). Heterotypic assembly has also been associated to amyloid transmissibility of neurodegenerative disorders and as a causative agent for the progression of certain forms of systemic amyloidosis (Westermark \& Westermark, 2010).

The observation that heterotypic interactions affect the mesoscopic structure of $A \beta$ fibrils in vitro suggests that such interactions can potentially also contribute to polymorphic bias in disease. Thus, next to specific posttranslational modifications and interaction with nonproteineous prosthetic ligands observed in amyloid cryoEM structures, heterotypic amyloid interactions could represent yet another way in which amyloid polymorphism can be affected by and possibly also affect the specific environment in which they are formed (Arakhamia et al, 2020; Scheres et al, 2020; Wesseling et al, 2020).

To evaluate whether heterotypic interactions occur in a neurodegenerative context we reevaluated deep proteomics data of human $A \beta$ plaques (Xiong et al., 2019). We found that sequences homologous to $A \beta$ APRs are enriched in plaques while this is not the case for non-APR segments of $A \beta$. While $A \beta$ plaques are of course mostly composed of $A \beta$ itself, the enrichment of these 'contaminants' suggests that heterotypic interactions occur in the process leading to plaque formation. Interestingly we do not find such enrichment in the $A \beta$ overexpression APP/PS1 mouse model. Possibly this could mean that in this case 
bioRxiv preprint doi: https://doi.org/10.1101/2021.04.28.441786; this version posted April 30, 2021. The copyright holder for this preprint (which was not certified by peer review) is the author/funder, who has granted bioRxiv a license to display the preprint in perpetuity. It is made available under aCC-BY-NC-ND 4.0 International license.

Konstantoulea, Guerreiro et al

overexpression is the dominant driver of plaque formation thereby outcompeting any possibility for heterotypic interaction. When analysing the function of heterotypic plaque components, we find that they mainly cluster in gene ontologies related to synaptic regulation and the regulation of vesicle-mediated transport suggesting that heterotypic interactions observed in plaques are associated to the synaptopathology of Alzheimer's disease (Forner et al, 2017). This raises the question of the nature of such association. Does heterotypic plaque composition reflect interactions that follow synaptic damage or do such interactions directly participate in the pathological chain of events resulting in synaptic breakdown? In the latter case the gain-of-function effects of heterotypic interactions could be bidirectional whereby protein interaction with $A \beta$ facilitates $A \beta$ initiation while $A \beta$ also perturbs the normal function of these proteins. Previous work with synthetic amyloids (Betti et al, 2016; Gallardo et al, 2016; Michiels et al, 2020), the inhibition of homologues by p53 tumor suppressor (Xu et al., 2011) or the inhibition of mammalian necroptosis by viral proteins supports the possibility that heterotypic amyloid interactions (Pham et al., 2019) can result in the functional knock down of target proteins. It is also probable that heterotypic interactions will be favoured in situations where proteins are (partially) unfolded e.g. during translation, translocation or due to physiological ageing implying additional spacial and temporal context.

It remains to be seen how the net result of the simultaneous expression of many homologous sequences adds up and to what degree these contribute to shaping neurodegenerative diseases. It also remains to be explored whether and how heterotypic amyloid interactions relate to genetic risk factors and to the complex pathophysiologic alterations observed in amyloid-associated neurodegenerative diseases. For now, we here present evidence for a generic molecular mechanism predisposing $A \beta$ amyloid structures to local sequence-specific gain-of-function binding interfaces allowing them to interact with specific proteins in a complex proteome. Thereby, these proteins affect the aggregation of $A \beta$ which in turn may functionally affecting these proteins by promoting co-assembly in amyloid deposits. 
bioRxiv preprint doi: https://doi.org/10.1101/2021.04.28.441786; this version posted April 30, 2021. The copyright holder for this preprint (which was not certified by peer review) is the author/funder, who has granted bioRxiv a license to display the preprint in perpetuity. It is made available under aCC-BY-NC-ND 4.0 International license.

Konstantoulea, Guerreiro et al 
bioRxiv preprint doi: https://doi.org/10.1101/2021.04.28.441786; this version posted April 30, 2021. The copyright holder for this preprint (which was not certified by peer review) is the author/funder, who has granted bioRxiv a license to display the preprint in perpetuity. It is made available under aCC-BY-NC-ND 4.0 International license.

Konstantoulea, Guerreiro et al

\section{Materials and Methods}

\section{In silico screening of $A B$ homologous $A P R$}

The human proteome (UniProt, 2008) was computational screen for protein sequence fragments that are highly similar to the APR of the $A \beta$ peptide (KLVFFA and LVFFAE), allowing maximum 2 mismatches within a hexapeptide. An inhouse generated algorithm was used to identify these homologue sequences. Approximately 600 homologous peptides were randomly picked from the human genome and further in-house synthetized/printed in membrane peptide arrays.

\section{Homologous peptide membrane arrays and A61-42 binding assay.}

The peptide arrays were developed through SPOT synthesis on acid stable cellulose membranes using the Intavis Multipep RSi synthesis robot. The peptides were synthetized, from C-terminus to N-terminus, starting with a GGS linker and containing a PEG spacer (Aims-Scientific). The obtained peptide array membranes were first incubated in $50 \%$ methanol for $10 \mathrm{~min}$, followed by three short washes in PBS-T (PBS, 0.05\% Tween-20). The membranes were blocked overnight in 1\% BSA in PBS-T, then washed for three times 5 min first in PBS-T and next in the incubation buffer (10 mM MES, $150 \mathrm{mM} \mathrm{NaCl}, 0.05 \%$ Tween$20, \mathrm{pH}$ 5.5). Then the membranes were incubated with Biot-Aß1-42 in incubation buffer supplemented with $100 \mathrm{mM}$ threhalose, for $1 \mathrm{~h}$ at room temperature.

The used Biot-A $\beta 1-42$ sample was obtained by solubilizing $0.1 \mathrm{mg}$ Biot-A $\beta 1-42$ ( $\mathrm{rPeptide}$ ) in HFIP for $1 \mathrm{~h}$, followed by $10 \mathrm{~min}$ water bath sonication, and finally drying under a $\mathrm{N}_{2}$ stream. The film was re-dissolved in $8 \mathrm{M}$ urea or $7 \mathrm{M} \mathrm{GnHCl}$ in $50 \mathrm{mM}$ Tris, $\mathrm{pH} 7.4$ and the sample was run over a Superdex 75 Increase 10/300 GL gel filtration column (GE Healthcare) equilibrated on the same buffer supplemented with or without $150 \mathrm{mM} \mathrm{NaCl}, 8 \mathrm{M}$ Urea respectively. The void peak of Biot-A $\beta 1-42$ was diluted 1:32 in the incubation buffer, with a final concentration of $0.25 \mathrm{M}$ urea. $10 \mu \mathrm{M}$ of monomeric Biotin-A $\beta 42$ was left to aggregate while measuring the ThT kinetics and $100 \mathrm{nM}$ of monomeric or different aggregating species were incubated in the membrane.

After the incubation with Biot-Aß1-42, membranes were washed four times 5 min in $A \beta$ incubation buffer, then in PBS-T, and then incubated with Streptavidin-poly HRP (Pierce 22140), diluted 1:100,000 in PBS-T, for $1 \mathrm{~h}$. Finally, membranes were washed in PBS-T for 
bioRxiv preprint doi: https://doi.org/10.1101/2021.04.28.441786; this version posted April 30, 2021. The copyright holder for this preprint (which was not certified by peer review) is the author/funder, who has granted bioRxiv a license to display the preprint in perpetuity. It is made available under aCC-BY-NC-ND 4.0 International license.

Konstantoulea, Guerreiro et al

three times 5 min and developed through chemiluminescence using a ChemiDoc XRS (BioRad).

\section{SEC-MALS analysis}

The MW of the Biot-A $\beta 1-42$ sample used in peptide membrane assays was studied using multi-angle light scattering (MALS) on a DAWN HELEOS MALS instrument from Wyatt Technology (Santa Barbara, CA, U.S.A.) with an incident laser wavelength of $658 \mathrm{~nm}$. The proteins were separated using a Superdex 75 Increase 10/300 GL gel filtration column (GE Healthcare) connected to an LC-10 Prominence HPLC system (Shimadzu), equilibrated with $50 \mathrm{mM}$ Tris, pH 7.4 containing $150 \mathrm{mM} \mathrm{NaCl}$, at a flow of $0.3 \mathrm{ml} / \mathrm{min}$ at RT. First, $25 \mu \mathrm{L}$ of a $2.0 \mathrm{mg} / \mathrm{mL}$ bovine serum albumin standard (Pierce) was injected. The scattering intensities at different angles were collected, corrected for the refractive indices of glass and solvent and normalized using the standard. Then, a $0.1 \mathrm{mg}$ Biot-Aß1-42 HFIP film was re-dissolved in $250 \mu \mathrm{L} 8 \mathrm{M}$ urea in $50 \mathrm{mM}$ Tris, $\mathrm{pH}$ 7.4, passed through a $0.2 \mu \mathrm{m}$ Spartan filter (Whatman) and $100 \mu \mathrm{L}$ was injected on the column. The value of $\mathrm{d} n / \mathrm{d} c$ (wherein $n$ is the refractive index of the solution and $c$ the solute concentration) was set to $0.185 \mathrm{~mL} / \mathrm{g}$ and the scattering data (collected at an interval of $0.5 \mathrm{~s}$ ) were then fitted according to Zimm formulation.

\section{Membranes analysis}

The signal for each spot in membrane was quantified using ImageLab (Biorad). 100 spots in the borders of the membrane was also quantified and the mean and SD of the background was calculated. We identified manually the lowest positive value for each membrane and calculated the Zscore $=\frac{\text { signal value-mean of background }}{\text { sd of background }}$. This Zscore was rounded up in an attempt to exclude the faint spots and labeled as Zcutoff. Each $Z$ value of spots was calculated and the ones higher than the Zcutoff identified as hits. Hits consistent in all 8 membranes were identified as interactors of $A \beta$.

\section{Purification of Met-AB1-42 (rAB1-42)}

The purification of the recombinant Met-A $\beta 1-42$ peptide was performed in-house based on the previously reported protocol (Walsh et al, 2009), using the human Met-A $\beta 1-42$ expression plasmid, a kind gift from C. Gomes (FCT, Lisbon). Briefly, the Met-Aß1-42 plasmid 
bioRxiv preprint doi: https://doi.org/10.1101/2021.04.28.441786; this version posted April 30, 2021. The copyright holder for this preprint (which was not certified by peer review) is the author/funder, who has granted bioRxiv a license to display the preprint in perpetuity. It is made available under aCC-BY-NC-ND 4.0 International license.

Konstantoulea, Guerreiro et al

was over-night expressed in E. coli, and used to inoculate $1 \mathrm{~L}$ of $\mathrm{M} 9$ culture medium, freshly supplemented with $50 \mathrm{mg} / \mathrm{ml}$ ampicillin and chloramphenicol, $2 \mathrm{mM} \mathrm{MgSO}_{4}, 0,1 \mathrm{mM} \mathrm{Ca}_{2} \mathrm{Cl}$ and $20 \%$ glucose. After reach an OD600: $0.6-0.8$, the expression of the plasmid was induced with $0.5 \mathrm{M}$ IPTG and leave to grow for $4 \mathrm{~h}$. The collected pellet was suspended in $10 \mathrm{mM}$ Tris, $1 \mathrm{mM}$ EDTA pH8, sonicated and centrifuged at 16000rpm and the final pellet dissolved in the same buffer supplemented with $8 \mathrm{M}$. After diluted to $2 \mathrm{M}$ urea, a first ion-exchange chromatography was performed in a DEAE Sepharose resin (GEHealthcare), using the suspension buffer supplemented with $25 \mathrm{mM} \mathrm{NaCl}$, as a binding buffer, and with $125 \mathrm{mM}$ $\mathrm{NaCl}$ as elution buffer. The purified solution was filtered in 30KD spin columns (GEHealthcare), further concentrated in a 3KD ones and the final sample lyophilized in vials with $1 \mathrm{mg}$ or $0.65 \mathrm{mg}$.

Prior to each experiment, the lyophilized sample was suspended for $1 \mathrm{~h}$ at room temperature in $800 \mathrm{ul}$ of $7 \mathrm{M} \mathrm{GuHCl}$ in $50 \mathrm{mM}$ Tris $\mathrm{pH} 8$, centrifuged $5 \mathrm{~min}$ at 15,000 rpm at $4^{\circ} \mathrm{C}$, and the supernatant injected (using $1 \mathrm{ml}$ injection loop) in a Superdex 75 10/300GL gel filtration column (GE Healthcare), previously equilibrated with $50 \mathrm{mM}$ Tris $\mathrm{pH} 8$ buffer. The fraction containing monomeric Met-A $\beta 1-42$ was collected and kept on ice, the concentration was determined in a NanoDrop 2000 (Thermo Fisher Scientific), using a molecular weight of 4645 Da and an extinction coefficient of 1.49. The sample was immediately used in several assays.

\section{Seeds}

Biot-A $A 1-42$ or $\mathrm{rA} \beta 1-42$ seeds were obtained by sonicating mature fibrils for $15 \mathrm{~min}$ (30sec on, $30 \mathrm{sec}$ off) at $10^{\circ} \mathrm{C}$ using Bioruptor Pico.

\section{ThT kinetic Assay}

10uM of monomeric Biot-A $\mathrm{B} 1-42$ in $50 \mathrm{mM}$ Tris $\mathrm{pH7.4}$ was pipetted to $\mu$ clear medium binding half area plates (Greiner, \#675096) and ThT was added to a final concentration of 25 $\mu \mathrm{M}$. ThT binding was measured over time (through excitation at $440 \mathrm{~nm}$ and emission at 480), using a Fluostar fluorescence plate reader (BMG Labtech) at $30^{\circ} \mathrm{C}$. ThT kinetics for biotin-A $\beta 42$ was done in a similar way by adding 5 or $10 \%$ of biotin seeds. 
bioRxiv preprint doi: https://doi.org/10.1101/2021.04.28.441786; this version posted April 30, 2021. The copyright holder for this preprint (which was not certified by peer review) is the author/funder, who has granted bioRxiv a license to display the preprint in perpetuity. It is made available under aCC-BY-NC-ND 4.0 International license.

Konstantoulea, Guerreiro et al

The monomeric samples of Met-A $\beta 1-42$ obtained after the purification protocol, described above, with a concentration of $10 \mu \mathrm{M}$ was incubated at $30^{\circ} \mathrm{C}$ with a constant shacking for 4 days.

All used peptides were purchased from Genscript, and in their design scheme have a GGS on the c-terminus, a PEG2 on both terminus and are acetylated and amidated, respectively on $\mathrm{N}$ and $\mathrm{C}$ terminus. Peptides were solubilized in HFIP, aliquoted in $0,25 \mathrm{mg}$ vials, dried under $\mathrm{N}_{2}$ stream and stored at $-20^{\circ} \mathrm{C}$. Peptide HFIP films were dissolved in $50 \mathrm{mM}$ Tris $\mathrm{pH} 8$ buffer, filtered through a 0.22 um Millex-GV spin filter and diluted to $20 \mu \mathrm{M}$. In-house purified MetA 1 1-42, described above, was diluted to $20 \mu \mathrm{M}$. Peptide and Met-Aß1-42 were mixed 1:1 with a final concentration of $10 \mu \mathrm{M}$ each, in $50 \mathrm{mM}$ Tris pH8 buffer. Mixtures containing only peptide or Met-Aß1-42 were used as controls.

The mixtures of $A \beta 1-42$ and the peptides were pipetted to a $\mu$ clear medium binding half area plates (Greiner, \#675096) and ThT was added to a final concentration of $25 \mu \mathrm{M}$. ThT binding was measured over time (through excitation at $440 \mathrm{~nm}$ and emission at 480), using a Fluostar fluorescence plate reader (BMG Labtech) at $30^{\circ} \mathrm{C}$, with a readout every 10 minutes and 10 seconds of shaking before each readout. Similar peptide:Met-A $1-42$ samples but without ThT, were include for further TEM imaging and pFTAA end-point measurements.

Data were normalized and fitted in ThT kinetics Fitting formula

$$
Y=y o+\left(\frac{(y m a x-y o)}{(1+\exp (-(x-x h a l f) * k)}\right)
$$

$\mathrm{T}_{1 / 2}$ and $\mathrm{k}$ was calculated from the formula above. Fluorescence amplitude was identified as the highest value of kinetics and lag time from, lagtime $=t_{1 / 2}-(2-k)$. Statistical analysis was performed using Brown-Forsythe and Welch ANOVA test with Dunnett T3 multiple comparisons correction and $95 \%$ confidence interval. Mean difference and $95 \% \mathrm{Cl}$ of difference was plotted. GraphPad was used for statistics and graphs.

\section{Transmission electron microscopy}

Once the ThT signal reach a plateau, the resulting fibrils from the peptide:rA $\beta 1-42$ samples were analysed for their structural characteristics. Therefore, 10ul of each sample was spotted in a copper grid (Formvar/Carbon on 400 Mesh Copper - AGAR SCI, AGS162-4), previously glow discharged. The sample was adsorbed for 3 minutes. Afterwards the grids 
bioRxiv preprint doi: https://doi.org/10.1101/2021.04.28.441786; this version posted April 30, 2021. The copyright holder for this preprint (which was not certified by peer review) is the author/funder, who has granted bioRxiv a license to display the preprint in perpetuity. It is made available under aCC-BY-NC-ND 4.0 International license.

Konstantoulea, Guerreiro et al

were washed by contact with three drops of $M Q$ water, negative stained with one drop of uranyl acetate $(2 \% \mathrm{w} / \mathrm{v})$ for one minute, and finally washed in a drop of $\mathrm{MQ}$ water. The grids were examined using a JEM-1400 120kV transmission electron microscope (Jeol, Japan), at accelerating voltage of $80 \mathrm{keV}$. At least 9 positions on the grid was used for quantification. Fibrils were quantified if they were able to be traced from start to end. More than 100 fibrils were quantified in most cases (except rAß1-42+P23, rAß1-42+P24) (Appendix Table S7). Length was measured by using the freehand line of Fiji and tracing the fibrils from start to end. Statistical analysis was performed using Brown- Forsythe and Welch ANOVA test with Games-Howell multiple comparisons correction and 99\% confidence intervals. GraphPad was used for statistics and graphs.

\section{Atomic force microscopy imaging}

Fibril samples were deposited on freshly cleaved mica for AFM imaging. Each sample was adjusted using a solution of $\mathrm{HCl}$ at a predetermined concentration to result in the sample reaching $\mathrm{pH}$ 2. Immediately afterwards, $20 \mu \mathrm{l}$ samples were deposited onto freshly cleaved mica surfaces (Agar scientific, F7013) and incubated for 5 minutes. Following incubation, the sample was washed with $1 \mathrm{ml}$ of filter sterilised milli-Q water and then dried using a stream of nitrogen gas. Fibrils were imaged using a Multimode AFM with a Nanoscope $V$ (Bruker) controller operating under peak-force tapping mode using ScanAsyst probes (silicon nitride triangular tip with tip height $=2.5-2.8 \mu \mathrm{m}$, nominal tip radius $=2 \mathrm{~nm}$, nominal spring constant $0.4 \mathrm{~N} / \mathrm{m}$, Bruker). Each collected image was scanned at either $4 \times 4 \mu \mathrm{m}$ and $2048 \mathrm{x}$ 2048 pixels or $8 \times 8 \mu \mathrm{m}$ and $4096 \times 4096$ pixels. Therefore, the same pixel density was maintained for all images within the dataset. A scan rate of $0.203 \mathrm{~Hz}$ was used. A noise threshold of $0.5 \mathrm{~nm}$ was used, and the $Z$ limit was reduced to $1.5 \mu \mathrm{m}$. Nanoscope analysis software (Version 1.5, Bruker) were used to process the image data by flattening the height topology data to remove tilt and scanner bow. Fibrils were traced (Aubrey et al., 2020; Xue et al, 2009), digitally straightened(Egelman, 1986), and surface envelope reconstructed as previously described(Aubrey et al., 2020; Lutter et al., 2020) using an in-house application. The height profile for each fibril was extracted from the centre contour line of the straightened fibrils from which the average height of each fibril was calculated.

\section{pFTAA and curcumin measurements}


bioRxiv preprint doi: https://doi.org/10.1101/2021.04.28.441786; this version posted April 30, 2021. The copyright holder for this preprint (which was not certified by peer review) is the author/funder, who has granted bioRxiv a license to display the preprint in perpetuity. It is made available under aCC-BY-NC-ND 4.0 International license.

Konstantoulea, Guerreiro et al

pFTAA and curcumin end-point measurements were performed on 3-day old peptide:MetAB1-42 samples, prepared as described above, using a final pFTAA concentration of $0.5 \mu \mathrm{M}$ and curcumin $5 \mu \mathrm{M}$. Measurements were done in a low-volume black 384-well plate (Corning) using a ClarioStar fluorescence plate reader (BMG Labtech). After excitation at 440 $\mathrm{nM}$, the emission spectra of pFTAA or curcumin were measured between $468 \mathrm{~nm}$ and 650 $\mathrm{nm}$. Curcumin spectra was normalized and tested for significance with Kolmogorov-Smirnov test using GraphPad. The ratio of the two pFTAA picks was calculated average $(505,506,507) /$ average $(530,539,540)$ and the statistical significance was calculated using Brown-Forsythe and Welch ANOVA test with Dunnett T3 multiple comparisons correction and 95\% confidence interval using GraphPad.

\section{HEK A61-42 biosensor cell line}

The $A \beta 1-42$ biosensor cell line was developed in house. Briefly, a $A \beta 1-42$ gene block was cloned in the multiple cloning site of a lentivirus plasmid, containing mCherry tag at $\mathrm{N}$ terminus and CMV as promoter. The plasmid was transfected in HEK cells, together with the packaging plasmids (pCMV-deltaR 8.9 and pCMV-VSV-G), for the production of viral particles. HEK cells were transduced with these viral particles and sorted for mCherry. Cells were diluted in 96 well plates and grown as single cell colonies. A colony showing diffused expression of mCherry-Aß1-42 was expanded and stored, to further be used as a biosensor cell line in $A \beta$ seeding assays.

\section{Seeding and transfection assay of biosensor A61-42 cell line}

The biosensor mCherry-Aß1-42 HEK cell line was cultured in DMEM medium, supplemented with $10 \% \mathrm{FBS}$ at $37^{\circ} \mathrm{C}$, and a $5 \% \mathrm{CO}_{2}$ atmosphere. The seeding assay was performed by transfecting these cells with freshly prepared $r A \beta 1-42$ seeds, described above, and the quantification of the formed $A \beta 1-42$ inclusions, resulted from the $A \beta 1-42$ aggregation.

Briefly, the assay was performed in 96-well plate (PerkinElmer), previously coated for 30' with poly-L-lysine at $37^{\circ} \mathrm{C}$ and washed three times with PBS. Adhered cells were passed twice through a $22 \mathrm{G}$ needle and plated at 15.000 cells/well and $5 \mathrm{~h}$ later were transfected with $0,10,50,100 \mathrm{nM}$ seeds or $100 \mathrm{ng}$ of DNA per well, using Lipofectamine 3000 (Invitrogen) according to the manufacturer. 
bioRxiv preprint doi: https://doi.org/10.1101/2021.04.28.441786; this version posted April 30, 2021. The copyright holder for this preprint (which was not certified by peer review) is the author/funder, who has granted bioRxiv a license to display the preprint in perpetuity. It is made available under aCC-BY-NC-ND 4.0 International license.

Konstantoulea, Guerreiro et al

After 17 hours of seed transfection and 41h of DNA transfection, the cells were fixed with 4\% formaldehyde in PBS for 10 minutes. Cells were washed with PBS, block and permeabilize with 1\%BSA, $0.2 \%$ TritonX-100 in PBS for 1hour. Cells were nuclei stained with 3uM Draq7 in 1\%BSA in PBS for $1 \mathrm{~h}$. Cells were washed and plates were imaged using Operetta CLS. For seeded cells: For each well 17 fields were imaged by using the channels Digital Phase Contrast, mCherry (Ex:530-560, Em:570-650), DRAQ7 (Ex:615-645, Em: 655705). The images were analysed by Operetta CLS. Nuclei was detected with DRAQ7, Cytoplasm with Digital Phase Contrast. Spots measured on ROls: Nuclei and Cell. For transfected cells: For each well 17 fields were imaged by using the channels Digital Phase Contrast, mCherry (Ex:530-560, Em:570-650), DRAQ7 (Ex:615-645, Em: 655-705), EGFP (Ex:460-490, Em: 500-550). The images were analysed by Operetta CLS. Nuclei was detected with DRAQ7, Cytoplasm with Digital Phase Contrast. Spots measured on ROls: Nuclei and Cell. EGFP intensity was measured for each cell identified. The baseline EGFP was calculated in PBS treated cells. Every cell with higher fluorescence was identified as transfected with our plasmids. The number of spots were identified in cells with and without EGFP fluorescence. No of spots per cell was calculated from No of spots/ no of cells for EGFP positive and negative cells (Appendix Table S8). Statistical significance was calculated using Ordinary one-way ANOVA with Dunett multiple comparison correction and unpaired t-test for comparison between transfected/nontransfected cells. GraphPad was used for statistics and graphs.

\section{FRAP}

Images were acquired on Nikon A1R Eclipse Ti confocal with Plan APO VC 60x oil lens. For mcherry excitation we used 561,6nm laser line and emission was collected at 570-620 nm. A pre-bleached image was acquired and ROI was bleached for $0.06,0.62,1.25 \mathrm{sec}$ at $100 \%$ power with 30 image acquisition for $1.91 \mathrm{sec}$ after each bleaching and 50 image acquisition after last bleaching. For seeds a similar protocol was used with bleaching for $0.06,0.62,1.25 \mathrm{sec}$ and 30 image acquisition of $0.97 \mathrm{sec}$ after each bleaching and 50 image acquisition after last bleaching. Live cell imaging was done at $37^{\circ} \mathrm{C}$ and $\mathrm{CO}_{2}$.

\section{Immunofluorescence}


bioRxiv preprint doi: https://doi.org/10.1101/2021.04.28.441786; this version posted April 30, 2021. The copyright holder for this preprint (which was not certified by peer review) is the author/funder, who has granted bioRxiv a license to display the preprint in perpetuity. It is made available under aCC-BY-NC-ND 4.0 International license.

Konstantoulea, Guerreiro et al

Cells were fixed with $4 \%$ formaldehyde in PBS for 10 minutes. Cells were washed with PBS, block and permeabilize with 1\%BSA, 0.2\% TritonX-100 in PBS for 1hour. Cells were stained with Alexa647 1:1000 in 1\%BSA in PBS for 1h. Images were acquired on Nikon A1R Eclipse Ti confocal with Plan APO VC 60x oil lens. For m-cherry excitation we used 561,6nm laser line and emission was collected at 570-620nm and for Alexa647 we used a 640.8 laser and the emission was measured at 663-738.

\section{Proteomic analysis}

$A \beta$ sequence was divided into hexapeptides with a sliding window. Proteins with absent values, \#Unique peptides $<1$ and Score Sequest $\mathrm{HT}<10$ were filtered out from the proteomic dataset(Xiong et al., 2019). The remaining proteins were searched for homology to $A \beta$ sequence with up to 2 mutations using an inhouse algorithm. Proteins with a fold change $>1.186$ was previously characterized as upregulated in APs, and defined the AP proteins. Enrichment ratios were calculated by

$$
\text { EnrichmentRatio }=\frac{\frac{\text { No of proteins with homology in AP }}{\text { No of AP proteins }}}{\frac{\text { No of proteins with homology in dataset }}{\text { No of proteins in dataset }}}
$$

Significance was calculated with hypergeometric test with Bonferroni correction for multiple comparisons. A similar approach was used for analyzing nonAD proteomic data, mouse data and Glial Cytoplasmic Inclusions.

In order to verify the significance of the observed enrichments of homologues peptides in AD plaque proteins, we asked how (un)likely it would be to observe these enrichments if the assignment of "AD-plaque-enriched" proteins was entirely random. To do so, we generated 1000 random samples of the same size of the set of proteins found to be enriched in $A D$ plaques by Xiong et al(Xiong et al., 2019). For each of these random samples, we calculated logFCs for the homologues peptides versus background (either MS dataset background or the entire proteome, as indicated). We then calculated $p$-values for the observed logFCs versus the distribution obtained through random sampling, assuming normality. Same approach was used for nonAD and mouse plaques.

Aggregation propensity of hexapeptides with homology to overrepresented regions of $A \beta$ from AP and non-AP proteins was calculated using TANGO. Statistical analysis was performed using Kolmogorov-Smirnov test. GraphPad Prism was used for statistical analysis. 
bioRxiv preprint doi: https://doi.org/10.1101/2021.04.28.441786; this version posted April 30, 2021. The copyright holder for this preprint (which was not certified by peer review) is the author/funder, who has granted bioRxiv a license to display the preprint in perpetuity. It is made available under aCC-BY-NC-ND 4.0 International license.

Konstantoulea, Guerreiro et al

Proteins identified in other MS studies were searched for homology to overrepresented $A \beta$ APRs, and pie charts of the proteins with homology versus proteins with no homology were plotted using GraphPad Prism.

Gene Ontologies of AP proteins with and without homology to A $\beta$ APRs were identified by using ClueGO(Bindea et al, 2009) plug-in of Cytoscape. Ontology used GO_BiologicalProcessEBI-UniProt-GOA_18.09.2019. Statistical analysis was performed with Right-sided hypergeometric test with Bonferroni step down multiple correction. Identified pathways and their p-values were imported in REVIGO(Supek et al, 2011). Pathways were summarized using Homo Sapiens database and SimRel as semantic similarity measure. TreeMap R script was downloaded and the most significant pathway in the group was used as representation. Full GO in supplementary. A similar approach was used for GO identification of nonAD brain AP proteins.

Glial cytoplasmic inclusions analysis was performed as previously, using as AP proteins the ones identified in purified Lewy Bodies from at least 4 MSA cases (McCormack et al., 2019). As background proteins we used proteins identified previously in human basal ganglia (Fernandez-Irigoyen et al., 2014)

\section{Acknowledgements}

The Switch Laboratory was supported by grants from the European Research Council under the European Union's Horizon 2020 Framework Programme ERC Grant agreement 647458 (MANGO) to JS, the Flanders institute for biotechnology (VIB), the University of Leuven ("Industrieel Onderzoeksfonds"), the Funds for Scientific Research Flanders (FWO) and the Flemish Agency for Work and Innovation (VLAIO). NL was supported by a post-doctoral fellowship from the FWO. LDA and WFX was supported by Biotechnology and Biological Sciences Research Council (BBSRC), UK grant BB/S003312/1.

LFR was supported by FWO 12N0319N and JdW by Alzheimer Research Foundation standard grant SAO-FRA 2019/0013 and Methusalem Grant of KU Leuven/Flemish Government The authors gratefully acknowledge Electron Microscopy Platform \& Bio Imaging Core, Department of Neurosciences KU Leuven, VIB - KU Leuven Center for Brain \& Disease 
bioRxiv preprint doi: https://doi.org/10.1101/2021.04 28.441786; this version posted April 30, 2021. The copyright holder for this preprint (which was not certified by peer review) is the author/funder, who has granted bioRxiv a license to display the preprint in perpetuity. It is made available under aCC-BY-NC-ND 4.0 International license.

Konstantoulea, Guerreiro et al

Research for their support \& assistance in this work. Nikon A1R Eclipse Ti confocal was acquired through a Hercules type 1 AKUL/097/037 grant to Wim Annaert.

\section{Conflicts of Interest}

Joost Schymkowitz and Frederic Rousseau are the scientific founders of, and scientific consultants to, Aelin Therapeutics NV. The Switch Laboratory is engaged in a collaboration research agreement with Aelin Therapeutics. 
bioRxiv preprint doi: https://doi.org/10.1101/2021.04.28.441786; this version posted April 30, 2021. The copyright holder for this preprint (which was not certified by peer review) is the author/funder, who has granted bioRxiv a license to display the preprint in perpetuity. It is made available under aCC-BY-NC-ND 4.0 International license.

Konstantoulea, Guerreiro et al

\section{References}

Aoyagi A, Condello C, Stohr J, Yue W, Rivera BM, Lee JC, Woerman AL, Halliday G, van Duinen S, Ingelsson M et al (2019) Abeta and tau prion-like activities decline with longevity in the Alzheimer's disease human brain. Science translational medicine 11

Arakhamia T, Lee CE, Carlomagno Y, Duong DM, Kundinger SR, Wang K, Williams D, DeTure M, Dickson DW, Cook CN et al (2020) Posttranslational Modifications Mediate the Structural Diversity of Tauopathy Strains. Cell 180: 633-644 e612

Aubrey LD, Blakeman BJF, Lutter L, Serpell CJ, Tuite MF, Serpell LC, Xue WF (2020) Quantification of amyloid fibril polymorphism by nano-morphometry reveals the individuality of filament assembly. Commun Chem 3

Betti C, Vanhoutte I, Coutuer S, De Rycke R, Mishev K, Vuylsteke M, Aesaert S, Rombaut D, Gallardo R, De Smet F et al (2016) Sequence-Specific Protein Aggregation Generates Defined Protein Knockdowns in Plants. Plant physiology 171: 773-787

Bindea G, Mlecnik B, Hackl H, Charoentong P, Tosolini M, Kirilovsky A, Fridman WH, Pages F, Trajanoski Z, Galon J (2009) ClueGO: a Cytoscape plug-in to decipher functionally grouped gene ontology and pathway annotation networks. Bioinformatics 25: 1091-1093

Bucciantini M, Calloni G, Chiti F, Formigli L, Nosi D, Dobson CM, Stefani M (2004) Pre-fibrillar amyloid protein aggregates share common features of cytotoxicity. J Biol Chem Bucciantini M, Giannoni E, Chiti F, Baroni F, Formigli L, Zurdo J, Taddei N, Ramponi G, Dobson CM, Stefani M (2002) Inherent toxicity of aggregates implies a common mechanism for protein misfolding diseases. Nature 416: 507-511.

Campioni S, Mannini B, Zampagni M, Pensalfini A, Parrini C, Evangelisti E, Relini A, Stefani M, Dobson CM, Cecchi C et al (2010) A causative link between the structure of aberrant protein oligomers and their toxicity. Nat Chem Biol 6: 140-147

Chang WP, Downs D, Huang XP, Da H, Fung KM, Tang J (2007) Amyloid-beta reduction by memapsin 2 (beta-secretase) immunization. FASEB J 21: 3184-3196

Chiti F, Dobson CM (2017) Protein Misfolding, Amyloid Formation, and Human Disease: A Summary of Progress Over the Last Decade. Annu Rev Biochem 86: 27-68

Ciryam P, Kundra R, Morimoto RI, Dobson CM, Vendruscolo M (2015) Supersaturation is a major driving force for protein aggregation in neurodegenerative diseases. Trends

Pharmacol Sci 36: 72-77

Colom-Cadena M, Gelpi E, Charif S, Belbin O, Blesa R, Marti MJ, Clarimon J, Lleo A (2013)

Confluence of alpha-synuclein, tau, and beta-amyloid pathologies in dementia with Lewy bodies. J Neuropathol Exp Neurol 72: 1203-1212

de la Paz ML, Serrano L (2004) Sequence determinants of amyloid fibril formation. Proc Nat/ Acad Sci U S A 101: 87-92

Dobson CM (1999) Protein misfolding, evolution and disease. Trends Biochem Sci 24: 329-

332

Egelman EH (1986) An Algorithm for Straightening Images of Curved Filamentous Structures. Ultramicroscopy 19: 367-373

Fernandez-Escamilla AM, Rousseau F, Schymkowitz J, Serrano L (2004a) Prediction of sequence-dependent and mutational effects on the aggregation of peptides and proteins. Nature Biotechnology 22: 1302-1306

Fernandez-Escamilla AM, Rousseau F, Schymkowitz J, Serrano L (2004b) Prediction of sequence-dependent and mutational effects on the aggregation of peptides and proteins. Nat Biotechnol 22: 1302-1306 
bioRxiv preprint doi: https://doi.org/10.1101/2021.04.28.441786; this version posted April 30, 2021. The copyright holder for this preprint (which was not certified by peer review) is the author/funder, who has granted bioRxiv a license to display the preprint in perpetuity. It is made available under aCC-BY-NC-ND 4.0 International license.

Konstantoulea, Guerreiro et al

Fernandez-Irigoyen J, Zelaya MV, Tunon T, Santamaria E (2014) Anatomo-proteomic characterization of human basal ganglia: focus on striatum and globus pallidus. Mol Brain 7: 83

Flagmeier P, De S, Michaels TCT, Yang X, Dear AJ, Emanuelsson C, Vendruscolo M, Linse S, Klenerman D, Knowles TPJ et al (2020) Direct measurement of lipid membrane disruption connects kinetics and toxicity of Abeta42 aggregation. Nat Struct Mol Biol

Forner S, Baglietto-Vargas D, Martini AC, Trujillo-Estrada L, LaFerla FM (2017) Synaptic Impairment in Alzheimer's Disease: A Dysregulated Symphony. Trends Neurosci 40: 347-357 Fu H, Hardy J, Duff KE (2018) Selective vulnerability in neurodegenerative diseases. Nat Neurosci 21: 1350-1358

Fu L, Niu B, Zhu Z, Wu S, Li W (2012) CD-HIT: accelerated for clustering the next-generation sequencing data. Bioinformatics 28: 3150-3152

Furukawa Y, Kaneko K, Matsumoto G, Kurosawa M, Nukina N (2009) Cross-seeding fibrillation of $\mathrm{Q} / \mathrm{N}$-rich proteins offers new pathomechanism of polyglutamine diseases. $J$ Neurosci 29: 5153-5162

Gallardo R, Ramakers M, De Smet F, Claes F, Khodaparast L, Khodaparast L, Couceiro JR, Langenberg T, Siemons M, Nystrom S et al (2016) De novo design of a biologically active amyloid. Science 354

Gallardo R, Ranson NA, Radford SE (2020) Amyloid structures: much more than just a crossbeta fold. Curr Opin Struct Biol 60: 7-16

Gan L, Cookson MR, Petrucelli L, La Spada AR (2018) Converging pathways in neurodegeneration, from genetics to mechanisms. Nat Neurosci 21: 1300-1309

Ganesan A, Debulpaep M, Wilkinson H, Van Durme J, De Baets G, Jonckheere W, Ramakers $M$, Ivarsson $Y$, Zimmermann $P$, Van Eldere J et al (2015) Selectivity of aggregationdetermining interactions. $J \mathrm{Mol}$ Biol 427: 236-247

Ganesan A, Siekierska A, Beerten J, Brams M, Van Durme J, De Baets G, Van der Kant R, Gallardo R, Ramakers M, Langenberg T et al (2016) Structural hot spots for the solubility of globular proteins. Nat Commun 7: 10816

Giasson BI, Forman MS, Higuchi M, Golbe LI, Graves CL, Kotzbauer PT, Trojanowski JQ, Lee VM-Y (2003) Initiation and Synergistic Fibrillization of Tau and Alpha-Synuclein. Science 300: 636-640

Goedert M, Eisenberg DS, Crowther RA (2017) Propagation of Tau Aggregates and Neurodegeneration. Annu Rev Neurosci 40: 189-210

Goldschmidt L, Teng PK, Riek R, Eisenberg D (2010) Identifying the amylome, proteins capable of forming amyloid-like fibrils. Proceedings of the National Academy of Sciences of the United States of America 107: 3487-3492

Hipp MS, Kasturi P, Hartl FU (2019) The proteostasis network and its decline in ageing. Nat Rev Mol Cell Biol 20: 421-435

Kaufman SK, Sanders DW, Thomas TL, Ruchinskas AJ, Vaquer-Alicea J, Sharma AM, Miller TM, Diamond MI (2016) Tau Prion Strains Dictate Patterns of Cell Pathology, Progression Rate, and Regional Vulnerability In Vivo. Neuron 92: 796-812

Kehrloesser S, Osterburg C, Tuppi M, Schafer B, Vousden KH, Dotsch V (2016) Intrinsic aggregation propensity of the $\mathrm{p} 63$ and $\mathrm{p} 73 \mathrm{TI}$ domains correlates with $\mathrm{p} 53 \mathrm{R} 175 \mathrm{H}$ interaction and suggests further significance of aggregation events in the p53 family. Cell death and differentiation 23: 1952-1960 Konstantoulea K, Louros N, Rousseau F, Schymkowitz J (2021) Heterotypic interactions in amyloid function and disease. FEBS J 
bioRxiv preprint doi: https://doi.org/10.1101/2021.04.28.441786; this version posted April 30, 2021. The copyright holder for this preprint (which was not certified by peer review) is the author/funder, who has granted bioRxiv a license to display the preprint in perpetuity. It is made available under aCC-BY-NC-ND 4.0 International license.

Konstantoulea, Guerreiro et al

Krebs MR, Morozova-Roche LA, Daniel K, Robinson CV, Dobson CM (2004) Observation of sequence specificity in the seeding of protein amyloid fibrils. Protein Sci 13: 1933-1938 Labbadia J, Morimoto RI (2015) The biology of proteostasis in aging and disease. Annu Rev Biochem 84: 435-464

Landreh M, Sawaya MR, Hipp MS, Eisenberg DS, Wuthrich K, Hartl FU (2016) The formation, function and regulation of amyloids: insights from structural biology. J Intern Med 280: 164176

Louros N, Konstantoulea K, De Vleeschouwer M, Ramakers M, Schymkowitz J, Rousseau F (2020) WALTZ-DB 2.0: an updated database containing structural information of experimentally determined amyloid-forming peptides. Nucleic Acids Res 48: D389-D393 Louros NN, Chrysina ED, Baltatzis GE, Patsouris ES, Hamodrakas SJ, Iconomidou VA (2016) A common 'aggregation-prone' interface possibly participates in the self-assembly of human zona pellucida proteins. FEBS Lett 590: 619-630

Lutter L, Serpell CJ, Tuite MF, Serpell LC, Xue WF (2020) Three-dimensional reconstruction of individual helical nano-filament structures from atomic force microscopy topographs.

Biomol Concepts 11: 102-115

Lutter L, Serpell CJ, Tuite MF, Xue WF (2019) The molecular lifecycle of amyloid - Mechanism of assembly, mesoscopic organisation, polymorphism, suprastructures, and biological consequences. Biochim Biophys Acta Proteins Proteom 1867: 140257

Ly H, Verma N, Sharma S, Kotiya D, Despa S, Abner EL, Nelson PT, Jicha GA, Wilcock DM, Goldstein LB et al (2021) The association of circulating amylin with $\beta$-amyloid in familial Alzheimer's disease. Alzheimer's \& Dementia: Translational Research \& Clinical Interventions 7: e12130

Mandal PK, Pettegrew JW, Masliah E, Hamilton RL, Mandal R (2006) Interaction between Abeta peptide and alpha synuclein: molecular mechanisms in overlapping pathology of Alzheimer's and Parkinson's in dementia with Lewy body disease. Neurochem Res 31: 11531162

Marshall KE, Vadukul DM, Dahal L, Theisen A, Fowler MW, Al-Hilaly Y, Ford L, Kemenes G, Day IJ, Staras K et al (2016) A critical role for the self-assembly of Amyloid-beta1-42 in neurodegeneration. Sci Rep 6: 30182

McCormack A, Keating DJ, Chegeni N, Colella A, Wang JJ, Chataway T (2019) Abundance of Synaptic Vesicle-Related Proteins in Alpha-Synuclein-Containing Protein Inclusions Suggests a Targeted Formation Mechanism. Neurotox Res 35: 883-897

Michiels E, Roose K, Gallardo R, Khodaparast L, Khodaparast L, van der Kant R, Siemons M, Houben B, Ramakers M, Wilkinson $\mathrm{H}$ et al (2020) Reverse engineering synthetic antiviral amyloids. Nature communications 11: 2832

Muratore CR, Zhou C, Liao M, Fernandez MA, Taylor WM, Lagomarsino VN, Pearse RV, 2nd, Rice HC, Negri JM, He A et al (2017) Cell-type Dependent Alzheimer's Disease Phenotypes: Probing the Biology of Selective Neuronal Vulnerability. Stem Cell Reports 9: 1868-1884 O'Nuallain B, Shivaprasad S, Kheterpal I, Wetzel R (2005) Thermodynamics of A beta(1-40) amyloid fibril elongation. Biochemistry 44: 12709-12718

O'Nuallain B, Williams AD, Westermark P, Wetzel R (2004) Seeding specificity in amyloid growth induced by heterologous fibrils. J Biol Chem 279: 17490-17499

Olzscha H, Schermann SM, Woerner AC, Pinkert S, Hecht MH, Tartaglia GG, Vendruscolo M, Hayer-Hartl M, Hartl FU, Vabulas RM (2011) Amyloid-like aggregates sequester numerous metastable proteins with essential cellular functions. Cell 144: 67-78 
bioRxiv preprint doi: https://doi.org/10.1101/2021.04.28.441786; this version posted April 30, 2021. The copyright holder for this preprint (which was not certified by peer review) is the author/funder, who has granted bioRxiv a license to display the preprint in perpetuity. It is made available under aCC-BY-NC-ND 4.0 International license.

Konstantoulea, Guerreiro et al

Oskarsson ME, Paulsson JF, Schultz SW, Ingelsson M, Westermark P, Westermark GT (2015) In vivo seeding and cross-seeding of localized amyloidosis: a molecular link between type 2 diabetes and Alzheimer disease. Am J Pathol 185: 834-846

Pham CL, Shanmugam N, Strange M, O'Carroll A, Brown JW, Sierecki E, Gambin Y, Steain M, Sunde M (2019) Viral M45 and necroptosis-associated proteins form heteromeric amyloid assemblies. EMBO Rep 20

Riek R, Eisenberg DS (2016) The activities of amyloids from a structural perspective. Nature 539: 227-235

Rousseau F, Schymkowitz J, Serrano L (2006a) Protein aggregation and amyloidosis: confusion of the kinds? Curr Opin Struct Biol 16: 118-126

Rousseau F, Schymkowitz JW, Wilkinson HR, Itzhaki LS (2001) Three-dimensional domain swapping in p13suc1 occurs in the unfolded state and is controlled by conserved proline residues. Proc Natl Acad Sci U S A 98: 5596-5601

Rousseau F, Serrano L, Schymkowitz JW (2006b) How evolutionary pressure against protein aggregation shaped chaperone specificity. J Mol Biol 355: 1037-1047

Sampson TR, Challis C, Jain N, Moiseyenko A, Ladinsky MS, Shastri GG, Thron T, Needham BD, Horvath I, Debelius JW et al (2020) A gut bacterial amyloid promotes alpha-synuclein aggregation and motor impairment in mice. Elife 9

Scheres SH, Zhang W, Falcon B, Goedert M (2020) Cryo-EM structures of tau filaments. Curr Opin Struct Biol 64: 17-25

Silva MVF, Loures CMG, Alves LCV, de Souza LC, Borges KBG, Carvalho MDG (2019)

Alzheimer's disease: risk factors and potentially protective measures. J Biomed Sci 26: 33

Supek F, Bosnjak M, Skunca N, Smuc T (2011) REVIGO summarizes and visualizes long lists of gene ontology terms. PLoS One 6: e21800

Tartaglia GG, Pechmann S, Dobson CM, Vendruscolo M (2007) Life on the edge: a link between gene expression levels and aggregation rates of human proteins. Trends in

Biochemical Sciences 32: 204-206

Taylor JP, Hardy J, Fischbeck KH (2002) Toxic proteins in neurodegenerative disease. Science 296: 1991-1995

Teng PK, Eisenberg D (2009) Short protein segments can drive a non-fibrillizing protein into the amyloid state. Protein Engineering Design \& Selection 22: 531-536

Tessier PM, Lindquist S (2007) Prion recognition elements govern nucleation, strain specificity and species barriers. Nature 447: 556-561

UniProt C (2008) The universal protein resource (UniProt). Nucleic Acids Res 36: D190-195

van der Kant R, Louros N, Schymkowitz J, Rousseau F (2021) A structural analysis of amyloid polymorphism in disease: clues for selective vulnerability? bioRxiv: 2021.2003.2001.433317 Vandersteen A, Masman MF, De Baets G, Jonckheere W, van der Werf K, Marrink SJ, Rozenski J, Benilova I, De Strooper B, Subramaniam V et al (2012) Molecular plasticity regulates oligomerization and cytotoxicity of the multipeptide-length amyloid-beta peptide pool. J Biol Chem 287: 36732-36743

Vanik DL, Surewicz KA, Surewicz WK (2004) Molecular basis of barriers for interspecies transmissibility of mammalian prions. Mol Cell 14: 139-145

Vasconcelos B, Stancu IC, Buist A, Bird M, Wang P, Vanoosthuyse A, Van Kolen K, Verheyen A, Kienlen-Campard P, Octave JN et al (2016) Heterotypic seeding of Tau fibrillization by preaggregated Abeta provides potent seeds for prion-like seeding and propagation of Taupathology in vivo. Acta Neuropathol 131: 549-569 


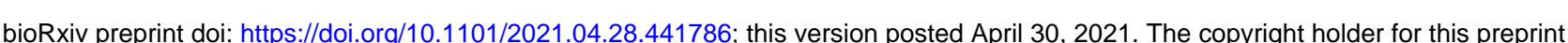
(which was not certified by peer review) is the author/funder, who has granted bioRxiv a license to display the preprint in perpetuity. It is made available under aCC-BY-NC-ND 4.0 International license.

Konstantoulea, Guerreiro et al

Ventura S, Zurdo J, Narayanan S, Parreno M, Mangues R, Reif B, Chiti F, Giannoni E, Dobson CM, Aviles FX et al (2004) Short amino acid stretches can mediate amyloid formation in globular proteins: the Src homology 3 (SH3) case. Proc Natl Acad Sci U S A 101: 7258-7263 Walsh DM, Selkoe DJ (2016) A critical appraisal of the pathogenic protein spread hypothesis of neurodegeneration. Nature reviews Neuroscience 17: 251-260

Walsh DM, Thulin E, Minogue AM, Gustavsson N, Pang E, Teplow DB, Linse S (2009) A facile method for expression and purification of the Alzheimer's disease-associated amyloid betapeptide. FEBS J 276: 1266-1281

Wang G, Fersht AR (2015) Propagation of aggregated p53: Cross-reaction and coaggregation vs. seeding. Proc Natl Acad Sci U S A 112: 2443-2448

Wesseling H, Mair W, Kumar M, Schlaffner CN, Tang S, Beerepoot P, Fatou B, Guise AJ, Cheng L, Takeda S et al (2020) Tau PTM Profiles Identify Patient Heterogeneity and Stages of Alzheimer's Disease. Cell 183: 1699-1713 e1613

Westermark GT, Westermark P (2010) Prion-like aggregates: infectious agents in human disease. Trends in molecular medicine 16: 501-507

Wetzel R (2006) Kinetics and thermodynamics of amyloid fibril assembly. Acc Chem Res 39: 671-679

Xiong F, Ge W, Ma C (2019) Quantitative proteomics reveals distinct composition of amyloid plaques in Alzheimer's disease. Alzheimers Dement 15: 429-440

Xu J, Reumers J, Couceiro JR, De Smet F, Gallardo R, Rudyak S, Cornelis A, Rozenski J, Zwolinska A, Marine JC et al (2011) Gain of function of mutant p53 by coaggregation with multiple tumor suppressors. Nat Chem Biol 7: 285-295

Xue WF, Homans SW, Radford SE (2009) Amyloid fibril length distribution quantified by atomic force microscopy single-particle image analysis. Protein Engineering Design \& Selection 22: 489-496

Yan L-M, Velkova A, Tatarek-Nossol M, Andreetto E, Kapurniotu A (2007) IAPP mimic blocks Abeta cytotoxic self-assembly: cross-suppression of amyloid toxicity of Abeta and IAPP suggests a molecular link between Alzheimer's disease and type II diabetes. Angewandte Chemie (International ed in English) 46: 1246-1252

Zaman M, Khan AN, Wahiduzzaman, Zakariya SM, Khan RH (2019) Protein misfolding, aggregation and mechanism of amyloid cytotoxicity: An overview and therapeutic strategies to inhibit aggregation. Int J Biol Macromol 134: 1022-1037

Zhou Y, Smith D, Leong BJ, Brannstrom K, Almqvist F, Chapman MR (2012) Promiscuous cross-seeding between bacterial amyloids promotes interspecies biofilms. J Biol Chem 287: 35092-35103 
bioRxiv preprint doi: https://doi.org/10.1101/2021.04.28.441786; this version posted April 30, 2021. The copyright holder for this preprint (which was not certified by peer review) is the author/funder, who has granted bioRxiv a license to display the preprint in perpetuity. It is made available under aCC-BY-NC-ND 4.0 International license.

Konstantoulea, Guerreiro et al

\section{Figure Legends}

1.Differential binding of $A \beta$ aggregating species in $A \beta$ cellulose peptide microarrays. a) $A \beta 1$ 42 sliding window membrane setup. Red indicates where the KLVFFA starts presented whole. Green where GAIIGL presented whole. Blue indicates the controls (4 proline breakers, 5 scrambled A $\beta$ peptides, sequences Supplementary Table1,3,5). b) SEC-MALS of Biot-Aß1-42 preparation with 7M GnHCL showing a clear monomeric peak and a smaller oligomeric. c) $100 \mathrm{nM}$ of Biot-Aß1-42 monomers show low binding on membrane (down panel), TEM image shows no aggregating species in the sample (upper panel) d) Void fraction (oligomers) show strong binding on first APR of AB1-42. e) Normalized ThT kinetics of $10 \mu \mathrm{M}$ Biot-A $\mathrm{B} 1-42$ with timepoints of samples that incubated with $A \beta 1-42$ membranes. $f-$ h) Binding of different aggregating samples to $A \beta$ membranes and their TEM images. 100nM of sample1 (early oligomers) binds strongly to middle APR (f), 100nM of sample2 (late oligomers) binds in both middle and C-terminal APR of AB1-42 (down panel) while TEM images shows fibrillar structures (upper panel) (g), 100nM of sample3 shows no specific binding to $A \beta 1-42$ membranes(h). i) ThT kinetics of Biot-A $\beta 1-42$ seeding. $10 \mu M$ of Biot-A $\beta 1-$ 42 incubated with 0.5 or $1 \mu \mathrm{M}$ of Biot-Aß1-42 seeds. j) $100 \mathrm{nM}$ of Biot-A $\beta 1-42$ seeds show a strong binding in both APRs.

2. $A \beta$ binding to APR homologues derived from human proteins. a) Sequence similarity in combination to peptide length for 1000 random proteins derived from human proteome. bc). Distribution of amino acids in homologues to A $\beta$ KLVFFA (b) and LVFFAE (c) proteins. d) Binding of Biot-A $\beta 1-42$ to homologue peptides derived from $\sim 520$ randomly selected proteins. e) Summary of Biot-A $\beta 1-42$ binding throughout 8 membranes, color indicates the mean between membranes and the size of the outline the standard deviation. f) Heatmap of amino acid substitutions in membrane hits. g-h) Membrane top binders spell AD and PLAK, white space consists of random sequences.

3. a-c) ThT kinetics of 10uM rAß1-42 alone or in presence (1:1) of 3 homologue peptides (full screen on Appendix Figure S3,S4, $n=2$ independent experiments with 4 repeats) d) Lag time difference between $r A \beta 1-42$ alone $(r A \beta 1-42=0)$ and in the presence of peptides (Statistics: Brown-Forsythe and Welch Anova tests with Dunnett T3 multiple comparison corrections) e) 
bioRxiv preprint doi: https://doi.org/10.1101/2021.04.28.441786; this version posted April 30, 2021. The copyright holder for this preprint (which was not certified by peer review) is the author/funder, who has granted bioRxiv a license to display the preprint in perpetuity. It is made available under aCC-BY-NC-ND 4.0 International license.

Konstantoulea, Guerreiro et al

Fluorescence amplitude difference between $r A \beta 1-42$ alone $(r A \beta 1-42=0)$ and in the presence of the peptides (Statistics: Brown-Forsythe and Welch Anova tests with Dunnett T3 multiple comparisons correction). f) Representative TEM images of fibrils made in presence of 1:1 rAß1-42:peptides. g) Fibril length difference between $A \beta$ alone and in presence of peptides (Statistics: Brown-Forsythe and Welch Anova test with Games-Howell multiple comparison correction). At least 9 different positions on grid and at least 100 fibrils were counted for each condition (except $A \beta+P 23, A \beta+P 24$ ). Fibril length distribution in Appendix Figure S7. h) Curcumin binding to $A \beta$ fibrils alone or in presence of $P 5$. ( $n=2$, at least 4 repeats, statistics: Kolmogorov-Smirnov test). i) Representative AFM height images of $A \beta$ fibrils alone or in a 1:1 mixture with $\mathrm{P} 3, \mathrm{P} 5, \mathrm{P} 8$ and $\mathrm{P} 12$ peptides are show in the top row. The boxes indicate the magnified regions shown in the second row. Arrows indicate the locations of representative individual fibrils shown in magnified detail, each shown as a 200 $\mathrm{nm}$ digitally straightened segment and a $100 \mathrm{~nm}$ segment of the corresponding 3D surface envelope model that was calculated from the image data. The scale bar for each row are shown to the left, with both the 3D model and the straightened image data representing 10 $\mathrm{nm}$. The colour scale of the 3D models from blue to yellow indicate the distance (from low to high) between the fibril surface and fibril centre axis to demonstrate their twist patterns. The average fibril height distribution of around 80 manually selected filaments per sample that showed twist patterns characteristic of single, not fragmented, amyloid fibrils are shown in the bottom row.

4. Proteins with homologues to $A \beta$ regions can induce the aggregation of $A \beta 1-42$ in HEK293T cells. a) Experimental setup of inducing aggregation in $A \beta$ biosensor cell line. $b$ ) Treating $A \beta$ biosensor with different concentration of $r A \beta 1-42$ seeds induces the aggregation of mCherry-A $\beta 1-42$ in a dose dependent matter ( $n=3$ independent experiments, graph: mean and $95 \% \mathrm{Cl}$ ). FRAP of $A \beta$ spots shows limited recovery confirming that are indeed aggregates (in detail at Appendix figure S10b,c). d) Representative images of 3 proteins that can induce aggregation of $A \beta 1-42$ in biosensor cell. Increase aggregation is observed in cells expressing the construct but not GFP alone (left panels). FRAP of the resulting aggregates shows no recovery (in detail at Appendix Figure S11). Removal of the homologue regions resulting in reduced aggregation (right panels). ( $n=3$ independent experiments). e) Quantification of number of spots per cell in cells expressing/not 
bioRxiv preprint doi: https://doi.org/10.1101/2021.04.28.441786; this version posted April 30, 2021. The copyright holder for this preprint (which was not certified by peer review) is the author/funder, who has granted bioRxiv a license to display the preprint in perpetuity. It is made available under aCC-BY-NC-ND 4.0 International license.

Konstantoulea, Guerreiro et al

expressing the construct (identified by GFP, transfection reporter) ( $n=3$ independent experiments, statistics: ordinary one-way Anova with Dunnett T3 multiple comparison correction, unpaired t-test for transfected/non-transfected cells). Bar plot: mean with $95 \% \mathrm{Cl}$. f-g) Quantification of Spots per cell for construct6 and construct6 control (6Ctrl, removal of homologue region) (f) and construct10 and construct10 control (10ctrl, removal of homologue region) (g). ( $\mathrm{n}=4$ independent experiments, statistics: ordinary one-way Anova). Bar plot: mean with $95 \% \mathrm{Cl}$. h-i) Confocal images of colocalization of protein of interest with $A \beta$ aggregates. (Contrast of images were enhanced to $0.1 \%$ saturated pixels using Fiji).

5. a) Overrepresentation of $A \beta$ APRs in amyloid plaques of $A D$ brains (hypergeometric test with Bonferroni correction) b) Log-odd ratio of random sampling from mass spectrometry background. Red dot indicated the true values of analysis c) Log-odd ratio of random sampling from human proteome. Red dot indicated the true values of analysis d) TANGO scores of homologue APRs in amyloid plaques and non-amyloid plaques proteins (statistics: Kolmogorov-Smirnov test) e) Biological pathways enrichment of A $\beta$ APR homologue related and non-related proteins derived from AD amyloid plaques f) APR homologue proteins identified in other MS studies g) Overrepresentation of AB APRs in amyloid plaques of nonAD brains. h) Log-odd ratio of random sampling from mass spectrometry background. Red dot indicated the true values of analysis i) Log-odd ratio of random sampling from human proteome. Red dot indicated the true values of analysis j) Biological pathways enrichment in nonAD amyloid plaques.

6.a) Overrepresentation of A $\beta$ APRs in amyloid plaques of APP/PS1 mouse brains (mean $\pm S D$ ) from two biological replicates. b) Log-odd ratio of random sampling from mass spectrometry background for both replicates. Red dot indicated the true values of analysis c) Log-odd ratio of random sampling from mouse proteome for both replicates. Red dot indicated the true values of analysis. d) No overrepresentation of A APRs was observed in proteins from Glial cytoplasmic inclusions. 
bioRxiv preprint doi: https://doi.org/10.1101/2021.04.28.441786; this version posted April 30, 2021. The copyright holder for this preprint (which was not certified by peer review) is the author/funder, who has granted bioRxiv a license to display the preprint in perpetuity. It is made available under aCC-BY-NC-ND 4.0 International license.

Konstantoulea, Guerreiro et al

\section{Tables}

Table 1: Summary of peptide screen

\begin{tabular}{|c|c|c|c|c|c|c|c|c|c|c|c|c|}
\hline $\begin{array}{l}\text { peptide } \\
\text { ID }\end{array}$ & sequence & UniProt ID & Protein Name & $\begin{array}{l}\text { Membrane } \\
\text { hits }\end{array}$ & $\begin{array}{l}\text { Lag } \\
\text { phase }\end{array}$ & Amplitude & $\begin{array}{l}\text { Fibril } \\
\text { Length } \\
\text { (TEM) }\end{array}$ & $\begin{array}{l}\text { Dye } \\
\text { binding }\end{array}$ & $\begin{array}{l}\text { Fibril } \\
\text { morphology } \\
\text { (AFM) }\end{array}$ & $\begin{array}{l}\text { biosensor } \\
\text { cells }\end{array}$ & $\begin{array}{l}\text { Amyloid } \\
\text { plaques } \\
\text { (Xiong et } \\
\text { al., 2019) }\end{array}$ & comments \\
\hline P1 & HRKSVFFVGQLGGS & Q562E7-1 & $\begin{array}{l}\text { WD repeat- } \\
\text { containing } \\
\text { protein } 81\end{array}$ & yes & ++ & & & & & & yes & $\begin{array}{l}\text { endolysosomal } \\
\text {, involved in } \\
\text { aggrephagy }\end{array}$ \\
\hline P2 & NPKLDFFKNFLGGS & 094822 & $\begin{array}{l}\text { E3 ubiquitin- } \\
\text { protein ligase } \\
\text { listerin }\end{array}$ & yes & - & - & & & & & yes & $\begin{array}{l}\text { part of } \\
\text { ribosomal } \\
\text { quality control } \\
\text { complex }\end{array}$ \\
\hline P3 & AVLRFFNEVFKGGS & P23786 & $\begin{array}{l}\text { Carnitine O- } \\
\text { palmitoyltransf } \\
\text { erase } 2\end{array}$ & yes & - & & ++ & & $X$ & ++ & yes & mitochondrial \\
\hline P4 & SQRLVGFALRRGGS & P51790-2 & $\begin{array}{l}\mathrm{H}(+) / \mathrm{Cl}(-) \\
\text { exchange } \\
\text { transporter } 3\end{array}$ & yes & ++ & & & & & + & yes & $\begin{array}{l}\text { endolysosomal } \\
\text {, involved in } \\
\text { acidification }\end{array}$ \\
\hline P5 & FMMTVFFAKKLGGS & 095196-1 & $\begin{array}{l}\text { Chondroitin } \\
\text { sulfate } \\
\text { proteoglycan } 5\end{array}$ & yes & $+t$ & -- & + & $\mathrm{X}$ & $\mathrm{X}$ & & & $\begin{array}{l}\text { neurogenesis, } \\
\text { trans-synaptic } \\
\text { signalling }\end{array}$ \\
\hline P6 & KHKPVAFAVRTGGS & $\begin{array}{ll}\text { P54284-1 } \\
\end{array}$ & $\begin{array}{l}\text { Voltage- } \\
\text { dependent L- } \\
\text { type calcium } \\
\text { channel } \\
\text { subunit beta-3 }\end{array}$ & yes & & & & & & & yes & $\begin{array}{l}\text { Presynaptic } \\
\text { depolarization } \\
\text { and calcium } \\
\text { channel } \\
\text { opening }\end{array}$ \\
\hline P7 & KGTVFFDEFTFGGS & 095497 & Pantetheinase & yes & & & + & & & & & $\begin{array}{l}\text { Inflammatory } \\
\text { response }\end{array}$ \\
\hline P8 & LPLVIFHELTKGGS & 015354 & $\begin{array}{l}\text { Prosaposin } \\
\text { receptor } \\
\text { GPR37 }\end{array}$ & yes & - & -- & + & & $X$ & & & $\begin{array}{l}\text { receptor for } \\
\text { neuroprotectiv } \\
\text { e factor }\end{array}$ \\
\hline P9 & DKLQFFEERRRGGS & Q15772-5 & $\begin{array}{l}\text { Striated muscle } \\
\text { preferentially } \\
\text { expressed } \\
\text { protein kinase }\end{array}$ & no & & & & & & & & $\begin{array}{l}\text { possible } \\
\text { growth } \\
\text { regulator in } \\
\text { muscle }\end{array}$ \\
\hline P10 & $\begin{array}{l}\text { PLSRVFFASWRGGS } \\
\end{array}$ & $\begin{array}{ll}\text { P05164-1 } \\
\end{array}$ & $\begin{array}{l}\text { Myeloperoxida } \\
\text { se }\end{array}$ & yes & ++ & & & & & & & $\begin{array}{l}\text { response to } \\
\text { oxidative stress }\end{array}$ \\
\hline P11 & DFRVFFQELVEGGS & Q92985-2 & $\begin{array}{l}\text { Interferon } \\
\text { regulatory } \\
\text { factor } 7\end{array}$ & yes & - & & & & & & & $\begin{array}{l}\text { transcription } \\
\text { factor } \\
\text { regulating } \\
\text { inflammation }\end{array}$ \\
\hline P12 & QRLVGFALRRDGGS & Q6ZZZ22 & 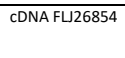 & yes & ++ & & - & & $x$ & & & unknown \\
\hline P13 & SGLSLFAETIWGGS & 000322 & Uroplakin-1a & yes & & & & & & & & $\begin{array}{l}\text { Component of } \\
\text { asymmetric } \\
\text { unit } \\
\text { memmbrane }\end{array}$ \\
\hline P14 & $\begin{array}{l}\text { SNLQFKAERIKGGS } \\
\end{array}$ & Q8TDM6-1 & $\begin{array}{l}\text { Disks large } \\
\text { homolog } 5\end{array}$ & yes & & & - & & & & & $\begin{array}{l}\text { Hippo } \\
\text { regulator, } \\
\text { synaptogenesis }\end{array}$ \\
\hline P15 & LLAVFFALGLEGGS & Q08462 & $\begin{array}{l}\text { Adenylate } \\
\text { cyclase type } 2\end{array}$ & no & & ++ & & & & & yes & $\begin{array}{l}\text { Catalyzes } \\
\text { cAMP in } \\
\text { response to G- } \\
\text { protein } \\
\text { signaling }\end{array}$ \\
\hline P16 & LRKLVRGATLDGGS & 095273-1 & $\begin{array}{l}\text { Cyclin-D1- } \\
\text { binding protein } \\
1\end{array}$ & yes & & & - & $\mathrm{X}$ & & & & $\begin{array}{l}\text { negative } \\
\text { regulator of } \\
\text { cell cycle } \\
\text { progression }\end{array}$ \\
\hline P17 & $\begin{array}{l}\text { PRKLDFFRSEKGGS } \\
\end{array}$ & 015031 & Plexin-B2 & yes & & & & $\mathrm{X}$ & & & yes & $\begin{array}{l}\text { Cell surface } \\
\text { receptor, } \\
\text { synapse } \\
\text { assembly }\end{array}$ \\
\hline P18 & FYLFFFTEKILGGS & Q15043-1 & $\begin{array}{l}\text { Metal cation } \\
\text { symporter } \\
\text { ZIP14 }\end{array}$ & yes & - & & & & & & yes & $\begin{array}{l}\text { metal ion } \\
\text { membrane } \\
\text { transporter }\end{array}$ \\
\hline P19 & FIFLRFFAPAIGGS & Q14644 & $\begin{array}{l}\text { Ras GTPase- } \\
\text { activating } \\
\text { protein } 3\end{array}$ & yes & - & & -- & & & & yes & $\begin{array}{l}\text { Inhibitory } \\
\text { regulator of } \\
\text { the Ras-cyclic }\end{array}$ \\
\hline
\end{tabular}


bioRxiv preprint doi: https://doi.org/10.1101/2021.04.28.441786; this version posted April 30, 2021. The copyright holder for this preprint (which was not certified by peer review) is the author/funder, who has granted bioRxiv a license to display the preprint in perpetuity. It is made available under aCC-BY-NC-ND 4.0 International license.

Konstantoulea, Guerreiro et al

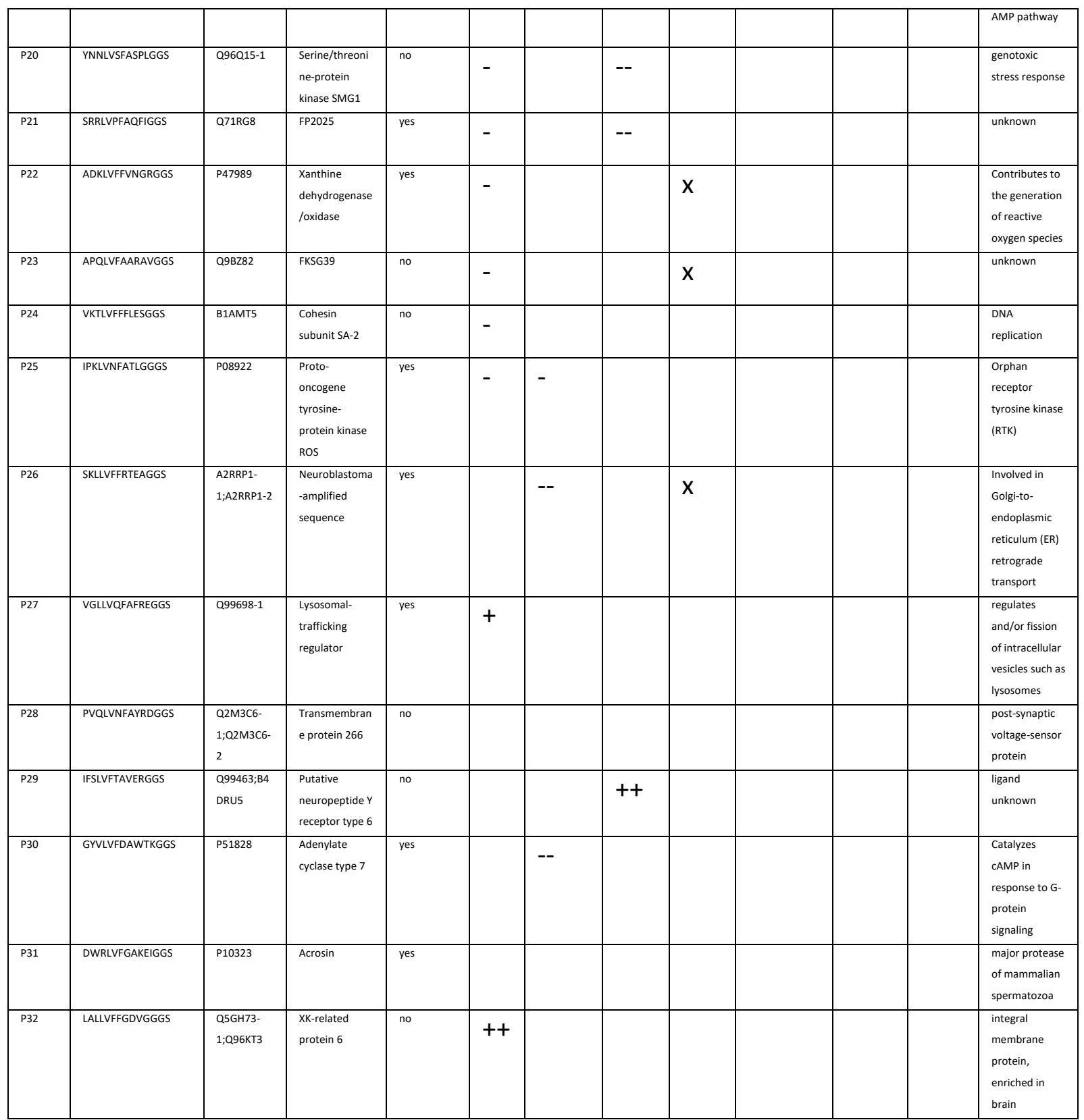

Table 2: Summary of constructs used in biosensor

\begin{tabular}{|c|c|c|c|c|c|c|}
\hline $\begin{array}{l}\text { No } \\
\text { Construct }\end{array}$ & Uniprot ID & Gene & Construct & Protein & Peptide ID & Comments \\
\hline 1 & Q02641-1 & CACNB1 & $\begin{array}{l}\text { HA-CACNB1-3xFLAG-IRES- } \\
\text { sfGFP }\end{array}$ & $\begin{array}{l}\text { Voltage-dependent L-type calcium channel } \\
\text { subunit beta-1 }\end{array}$ & - & $\begin{array}{l}\text { subunit of calcium type L- type. GO cellular response to amyloid- } \\
\text { beta }\end{array}$ \\
\hline 2 & Q9BY11-1 & PASCIN1 & $\begin{array}{l}\text { HA-PACSIN1-3xFLAG-IRES- } \\
\text { SfGFP }\end{array}$ & $\begin{array}{l}\text { Protein kinase } \mathrm{C} \text { and casein kinase substrate } \\
\text { in neurons protein } 1\end{array}$ & - & $\begin{array}{l}\text { Role in organization of microtubules. Role in synaptic vesicle } \\
\text { endocytosis }\end{array}$ \\
\hline 3 & 095196-1 & CSPG5 & $\begin{array}{l}\text { HA-CSPG5-3xFLAG-IRES- } \\
\text { sfGFP }\end{array}$ & Chondroitin sulfate proteoglycan 5 & 5 & neurogenesis, trans-synaptic signaling \\
\hline 4 & P54284-1 & CACNB3 & $\begin{array}{l}\text { HA-CACNB3-3xFLAG-IRES- } \\
\text { sfGFP }\end{array}$ & $\begin{array}{l}\text { Voltage-dependent L-type calcium channel } \\
\text { subunit beta-3 }\end{array}$ & 6 & Presynaptic depolarization and calcium channel opening \\
\hline 5 & $\begin{array}{l}\text { P04083-1 } \\
\end{array}$ & ANXA1 & $\begin{array}{l}\text { HA-ANXA1-3xFLAG-IRES- } \\
\text { SfGFP }\end{array}$ & Annexin A1 & - & Role in immune response \\
\hline 6 & P23786-1 & CPT2 & $\begin{array}{l}\text { HA-CPT2(2-600aa)-3xFLAG- } \\
\text { IRES-sfGFP }\end{array}$ & $\begin{array}{l}\text { Carnitine O-palmitoyltransferase } 2 \text {, } \\
\text { mitochondrial }\end{array}$ & 3 & mitochondrial \\
\hline 7 & 095497-1 & VNN1 & $\begin{array}{l}\text { HA-VNN1-3xFLAG-IRES- } \\
\text { sfGFP }\end{array}$ & Pantetheinase & 7 & Inflammatory response \\
\hline 8 & Q2M3C6-1 & TMEM266 & $\begin{array}{l}\text { HA-TMEM266-3xFLAG-IRES- } \\
\text { sfGFP }\end{array}$ & Transmembrane protein 266 & 28 & post-synaptic voltage-sensor protein \\
\hline
\end{tabular}


bioRxiv preprint doi: https://doi.org/10.1101/2021.04.28.441786; this version posted April 30, 2021. The copyright holder for this preprint (which was not certified by peer review) is the author/funder, who has granted bioRxiv a license to display the preprint in perpetuity. It is made available under aCC-BY-NC-ND 4.0 International license.

Konstantoulea, Guerreiro et al

\begin{tabular}{|l|l|l|l|l|l|l|}
\hline 9 & P51790-1 & CLCN3 & $\begin{array}{l}\text { HA-CLCN3(2-720aa)- } \\
\text { 3xFLAG-RES-sGGP }\end{array}$ & H(t)/CII-) exchange transporter 3 & 4 & endolysosomal, involved in acidification \\
\hline 10 & $060733-1$ & PLPL9 & $\begin{array}{l}\text { HA-PLPL-3xFLAG-IRES- } \\
\text { sfGFP }\end{array}$ & $\begin{array}{l}85 / 88 \text { kDa calcium-independent } \\
\text { phospholipase A2 }\end{array}$ & - & $\begin{array}{l}\text { Phospholipase involved in mitochondria integridy, membrane } \\
\text { homeostasis and signal transduction. }\end{array}$ \\
\hline GFP & P42212-1 & GFP & HA-GFP-3xFLLG-IRES-sfGFP & Green fluoresence protein & & \\
\hline
\end{tabular}


DAEFRHDSGYEVHHQ KLVFFA EDVGDNK GAIIGLMVGGVVIA

- - - - - - - - - - -

10000000000

10000000000

10000000000

10000000000

$\mathbf{a} L-\underline{\text { Proline Breakers }}-$ Scrambled $\_-b$

e
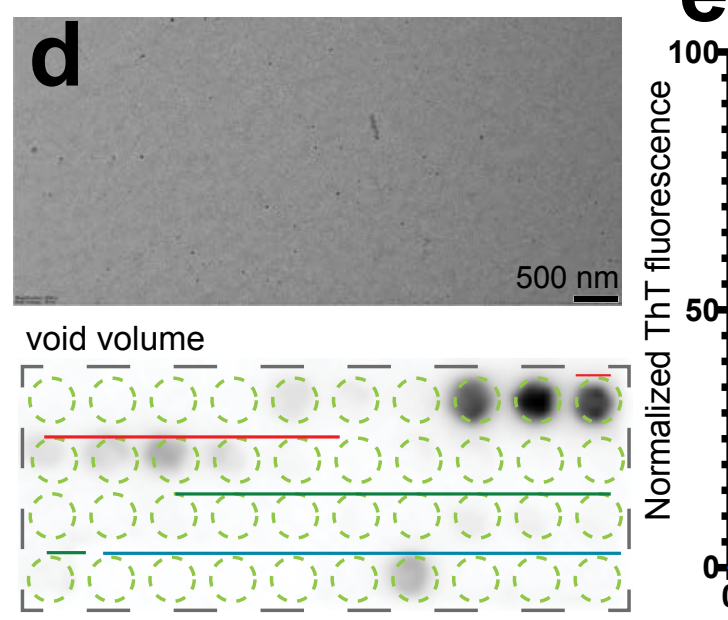

h

$500 \underline{\mathrm{nm}}$

sample 3

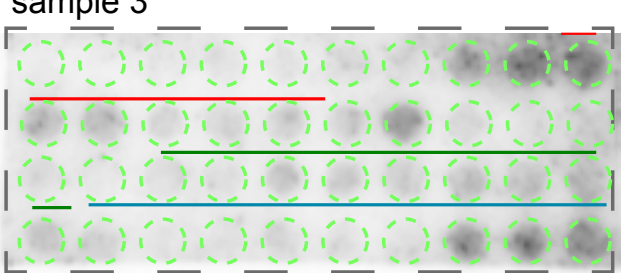

100 $10 u M$ Biot-AB42

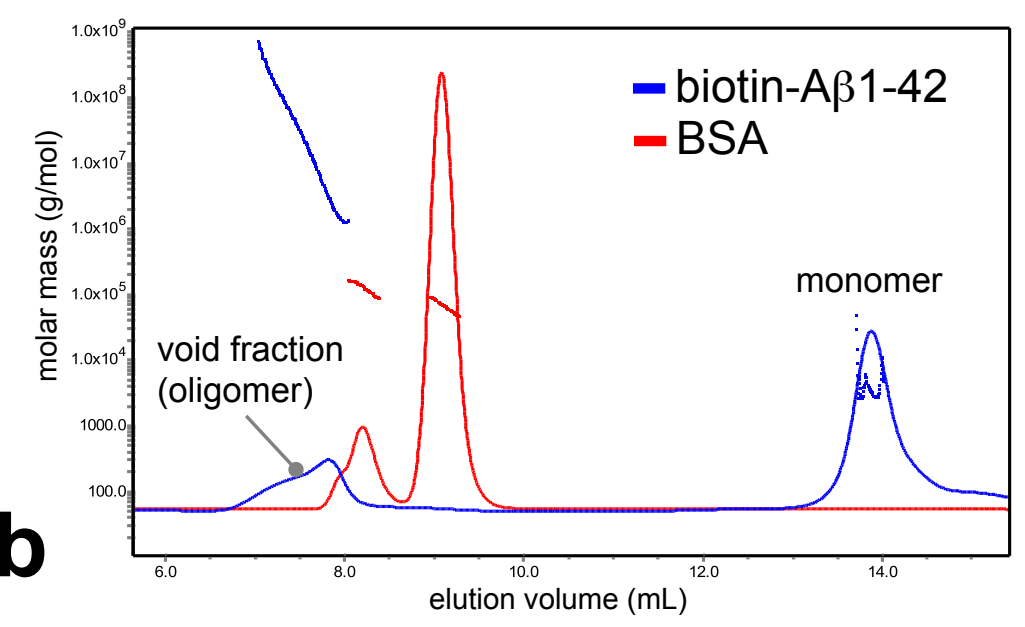

sample 3

f

f

$500 \underline{\mathrm{nm}}$

sample 1

F, $\bar{c} \overline{0}$

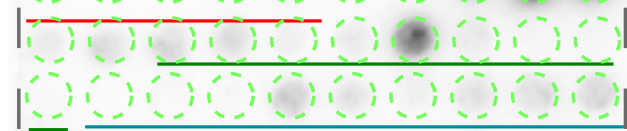

s

$40+1+1+10$
Time (h)

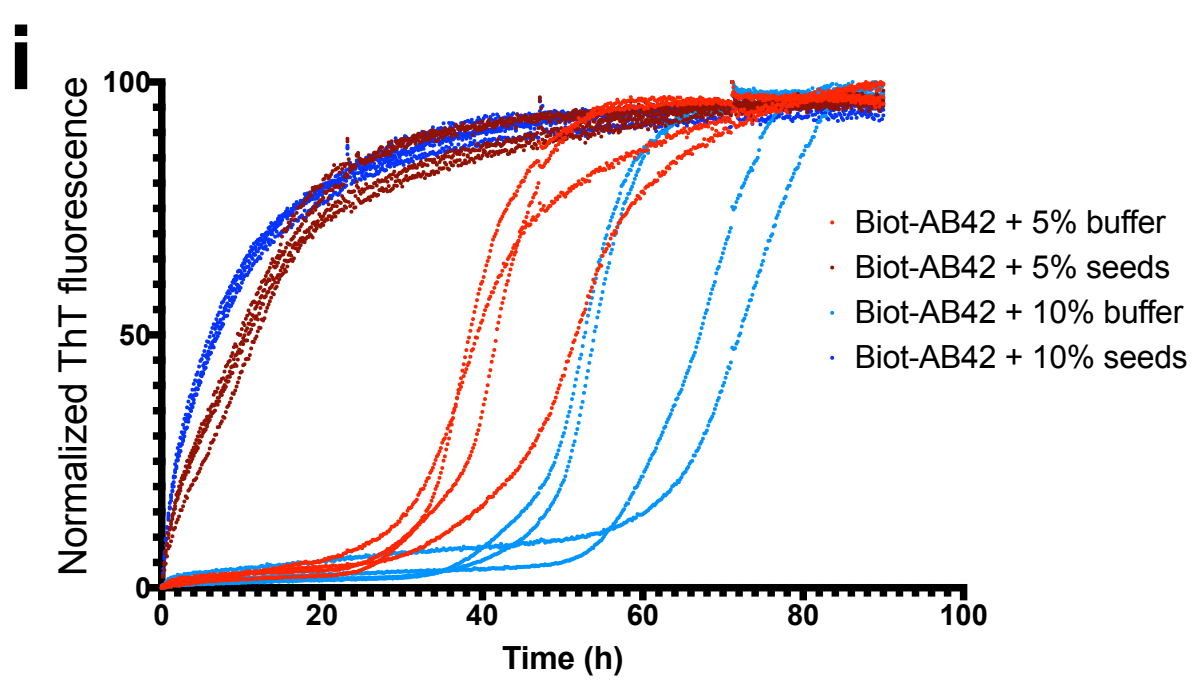

C

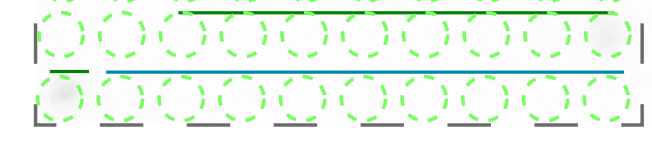

\section{g}

$500 \mathrm{~nm}$

sample 2
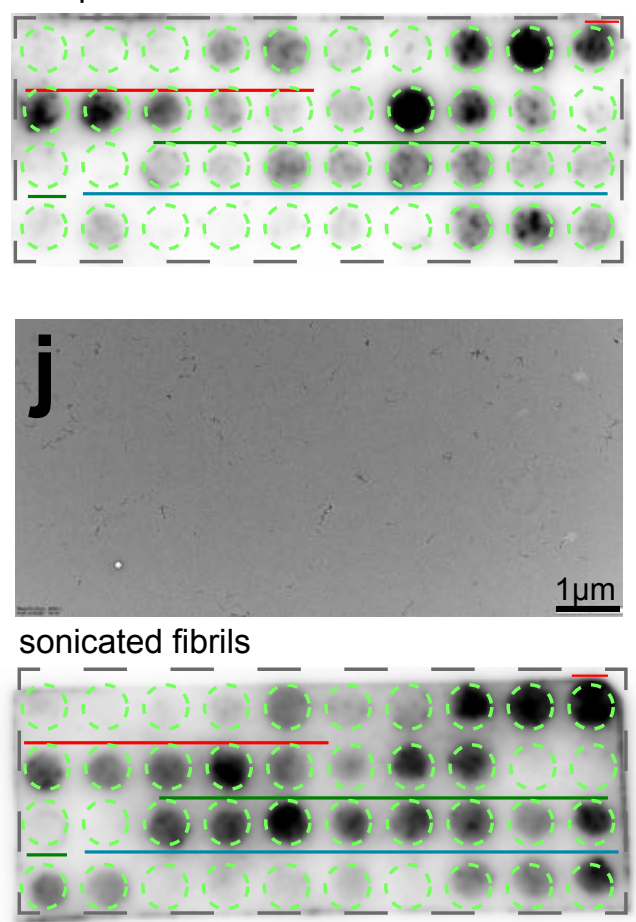

Konstantoulea, Guerreiro, et al - Figure 1 


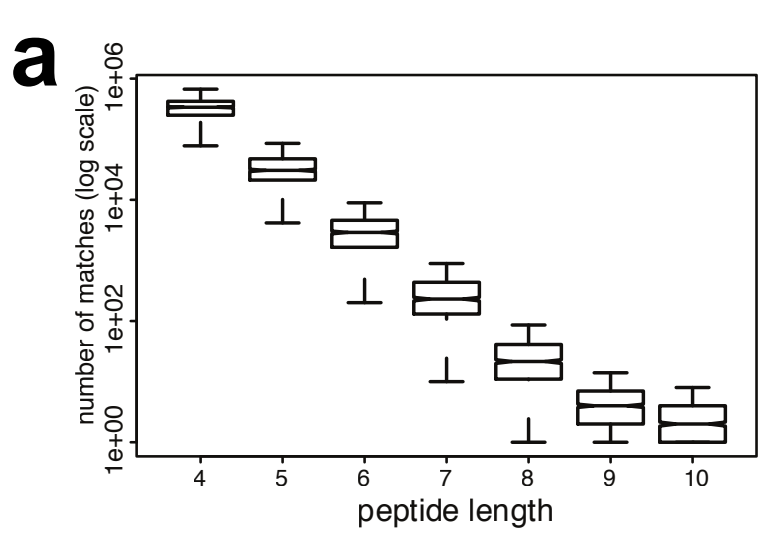

d

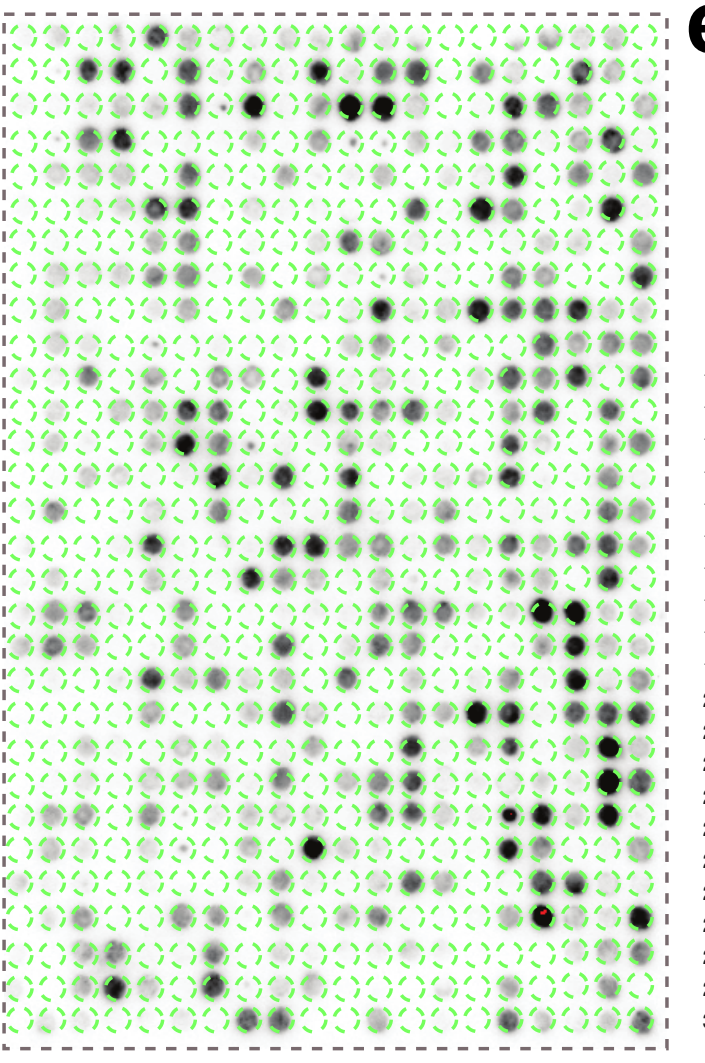

\section{e}

b

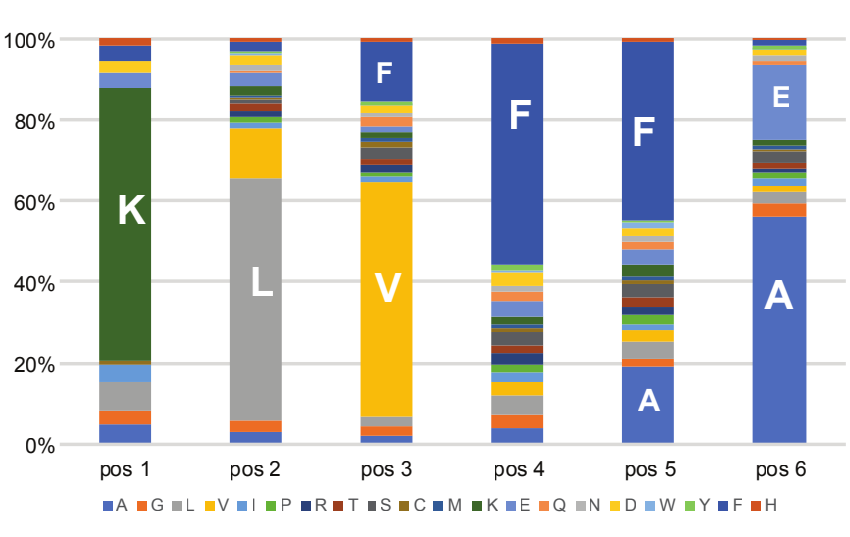

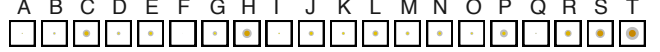

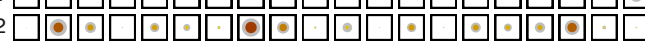

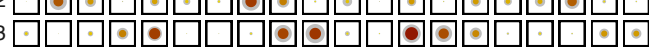

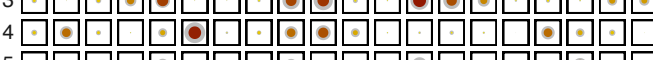

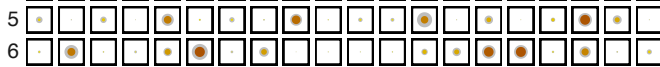

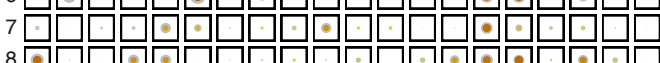
\&

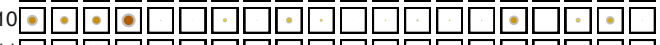

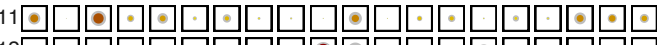

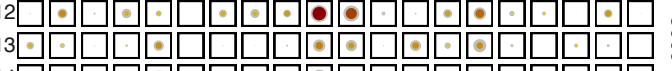

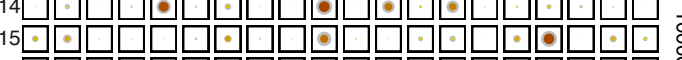

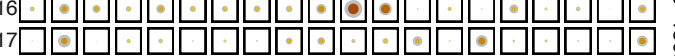
18 

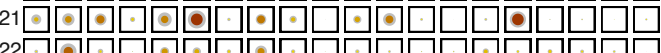

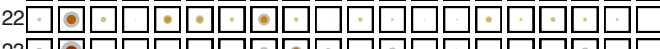

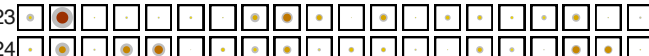

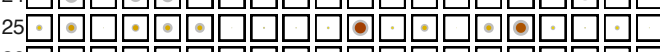

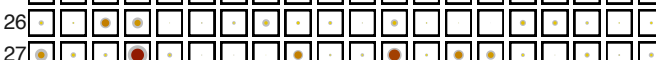

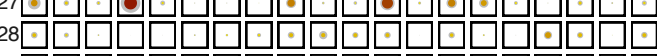

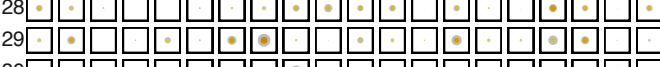
30
$\mathbf{C}_{100}$

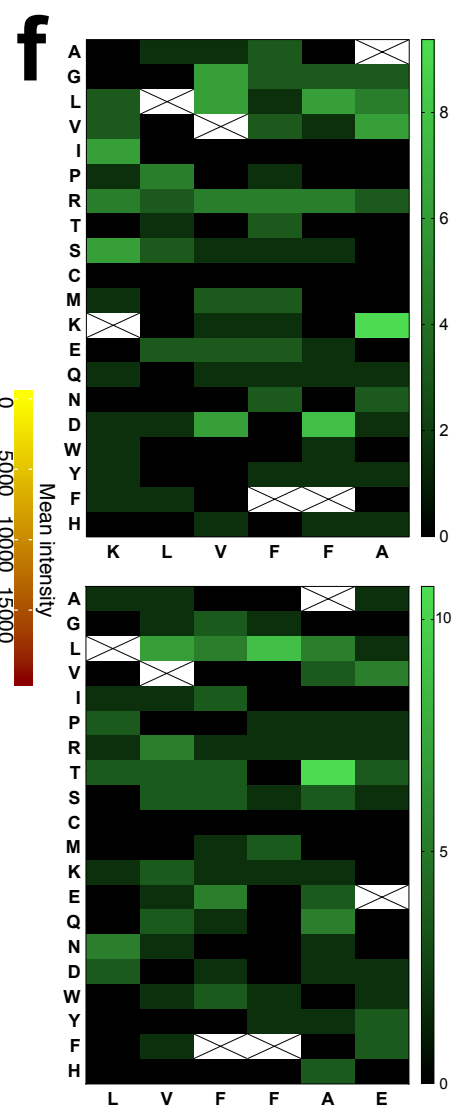

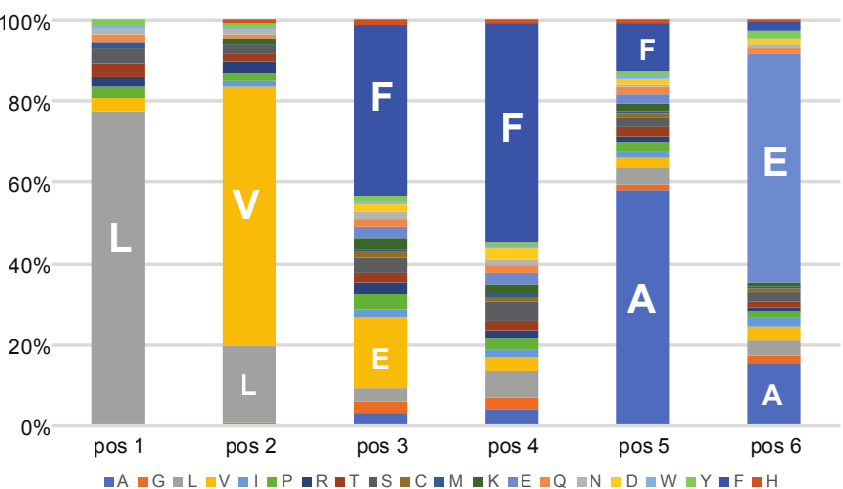

g

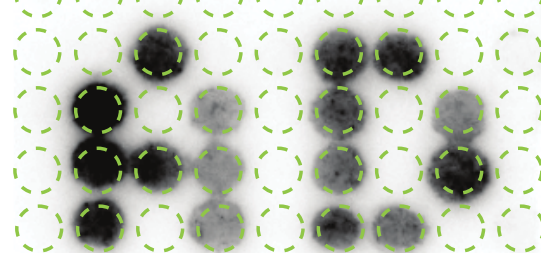

\section{h}

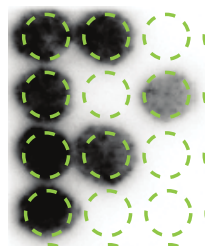




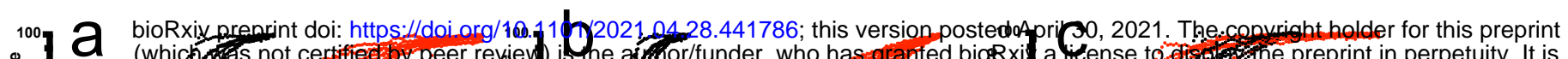
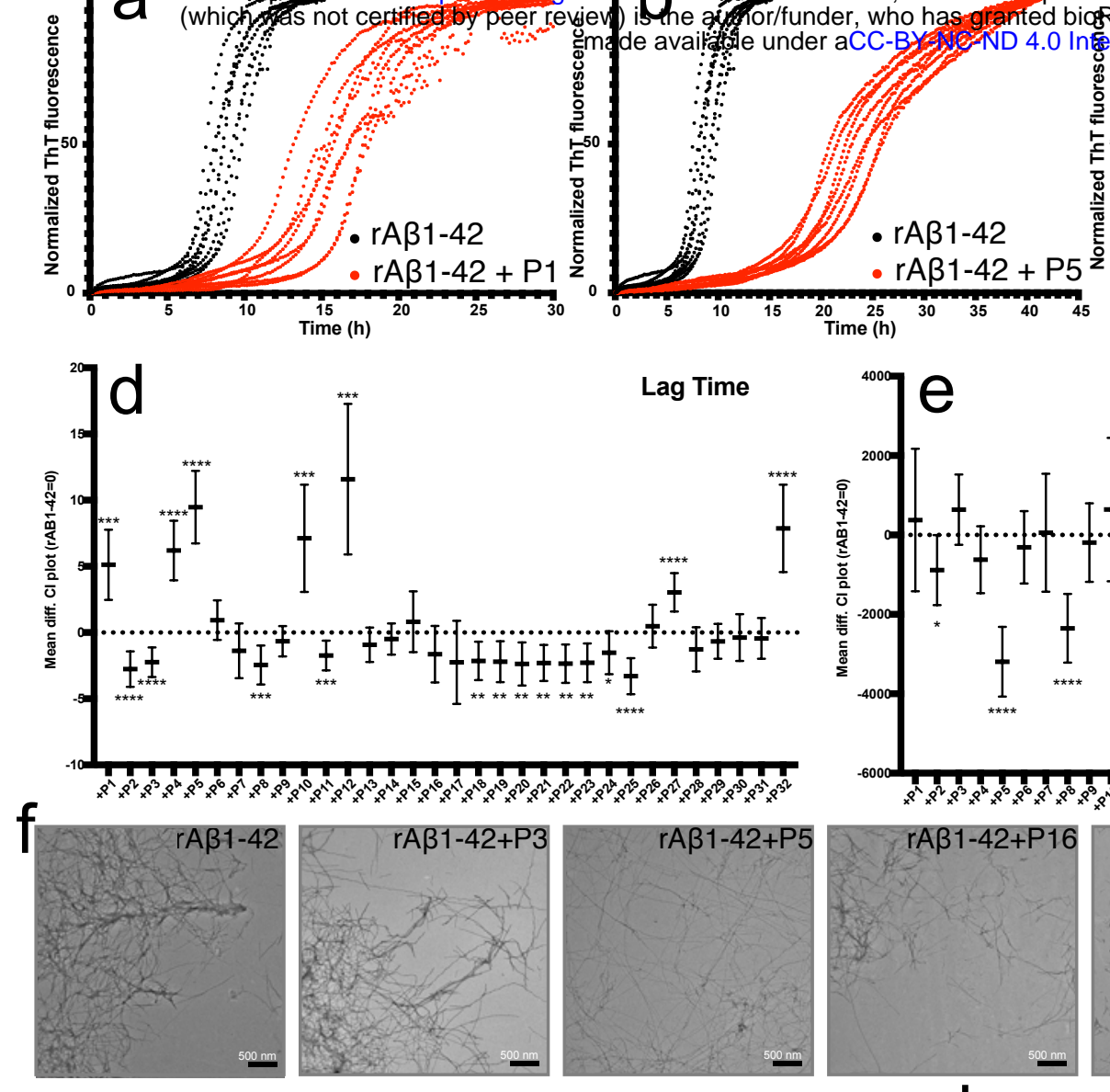

Lag Time
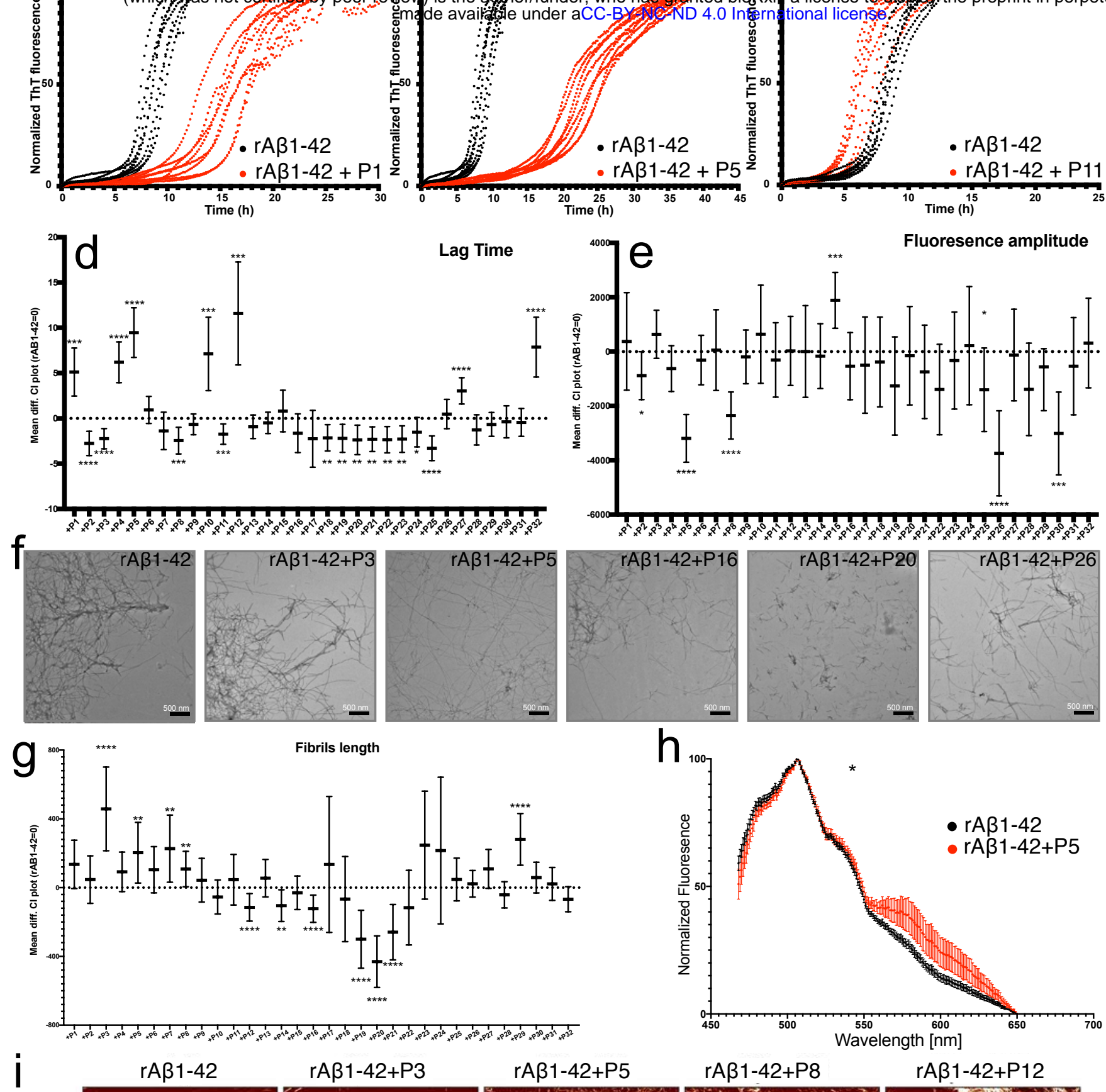

I

$\mathrm{rA \beta 1-42}$

$\mathrm{rA} \beta 1-42+\mathrm{P} 3$

$\mathrm{rAB1}-42+\mathrm{P} 5$
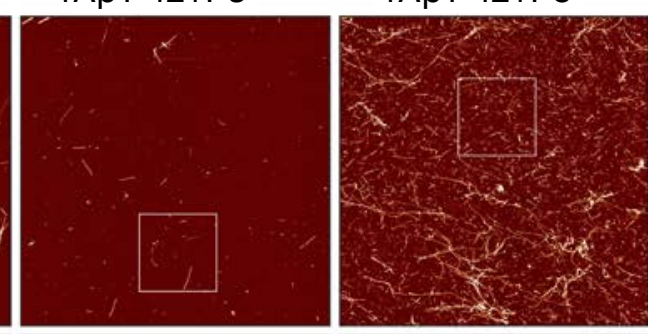

$r A \beta 1-42+P 8$

Fluoresence amplitude

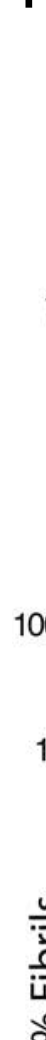

$1 \mu \mathrm{m} \mathbf{I}$
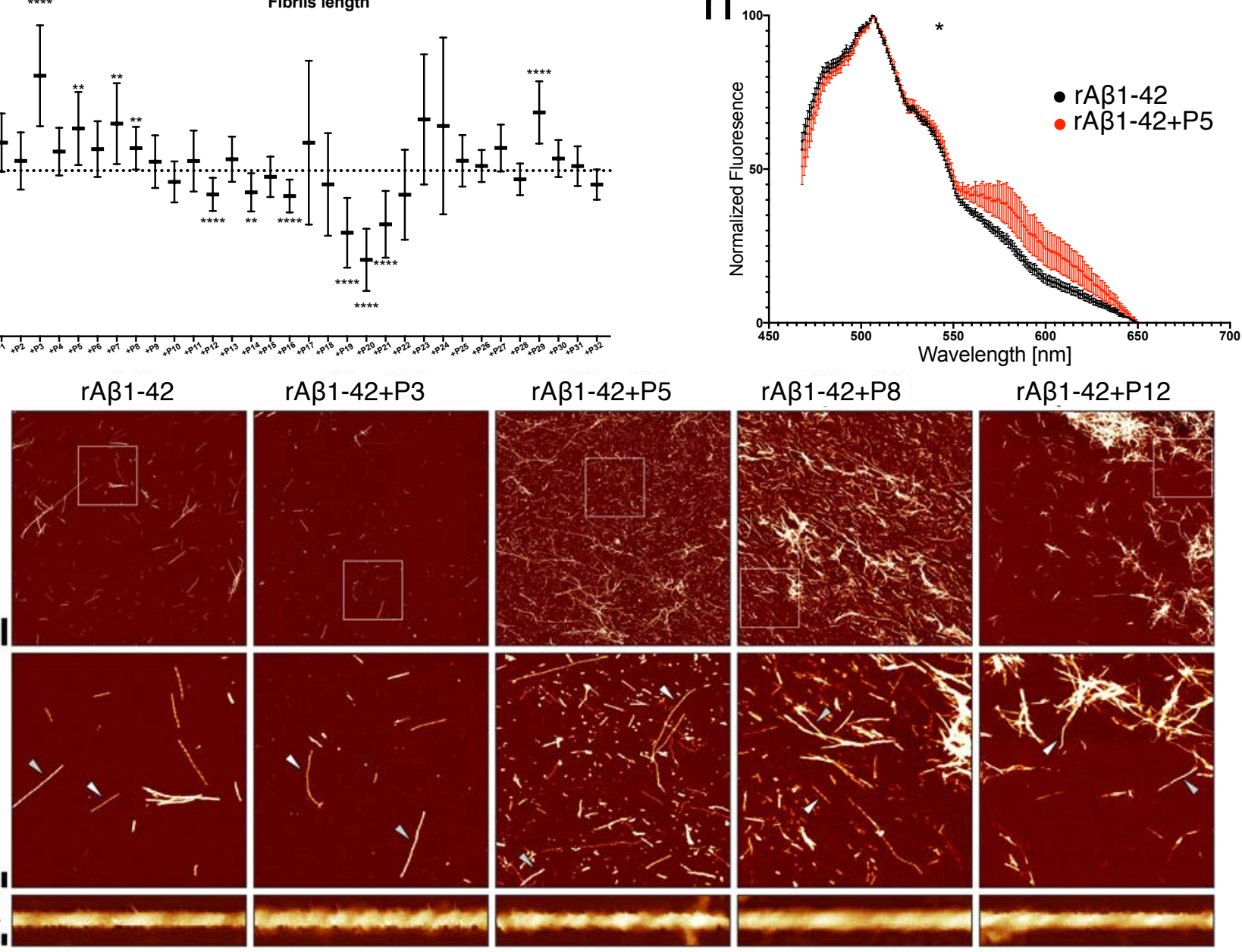

$10 \mathrm{~nm}$
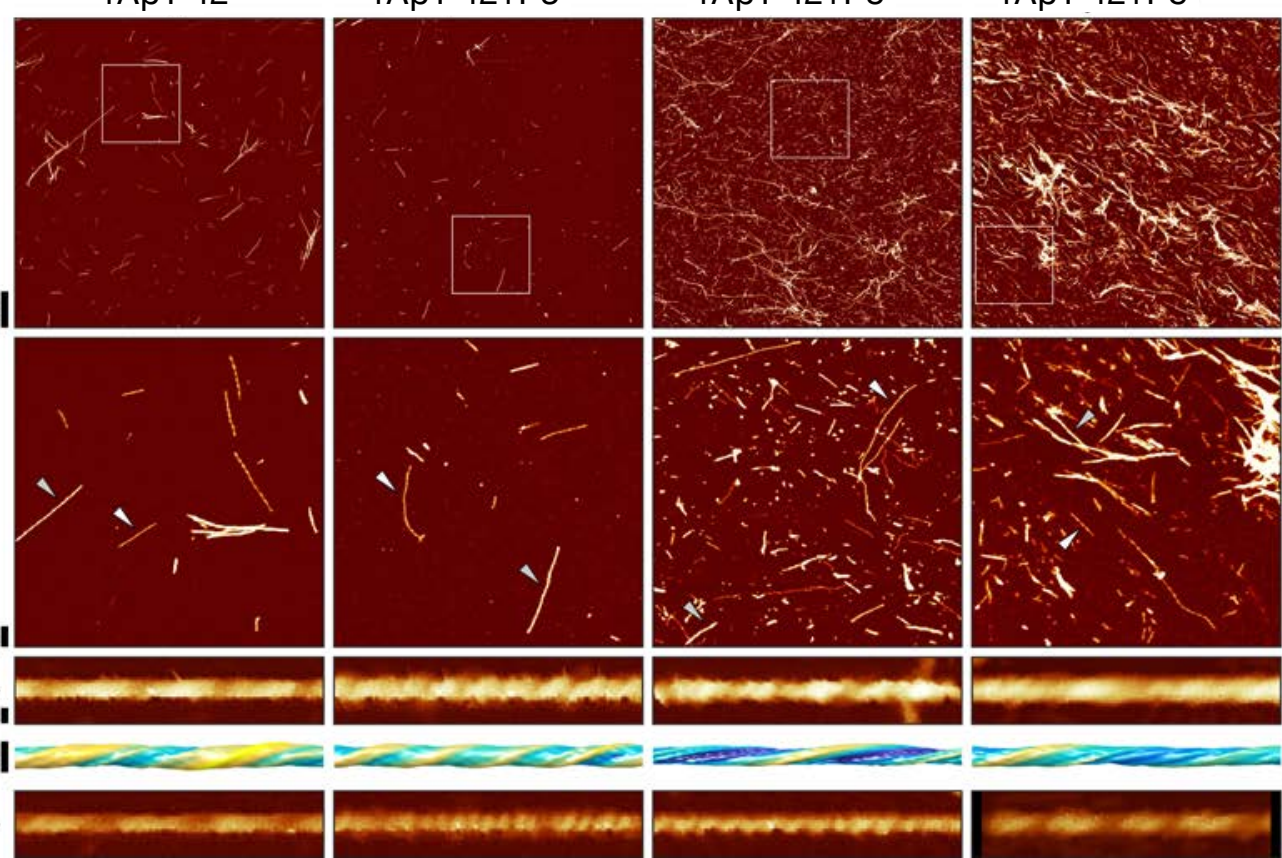

$r A \beta 1-42+P 12$
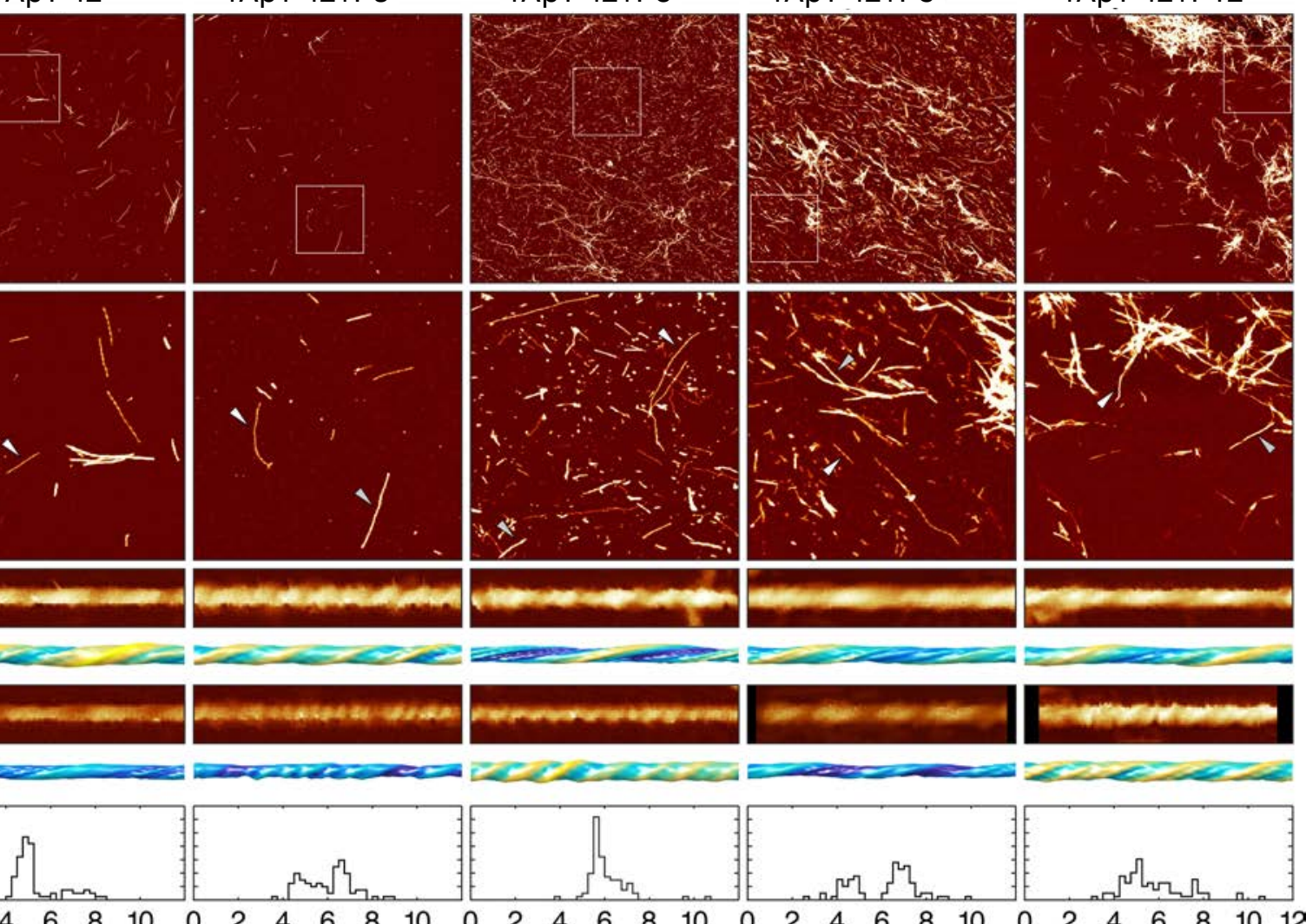

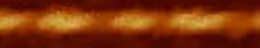

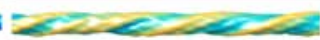




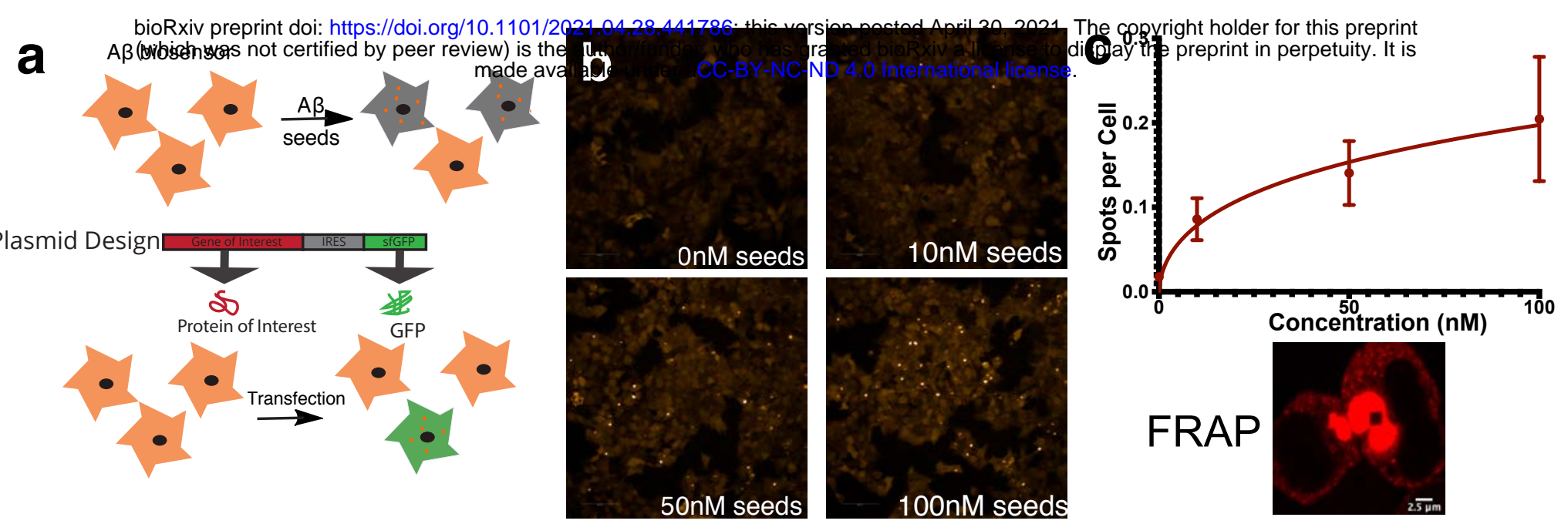

\section{d mCherry GFP Merged FRAP (Aß1-42) (Transfection Reporter)}

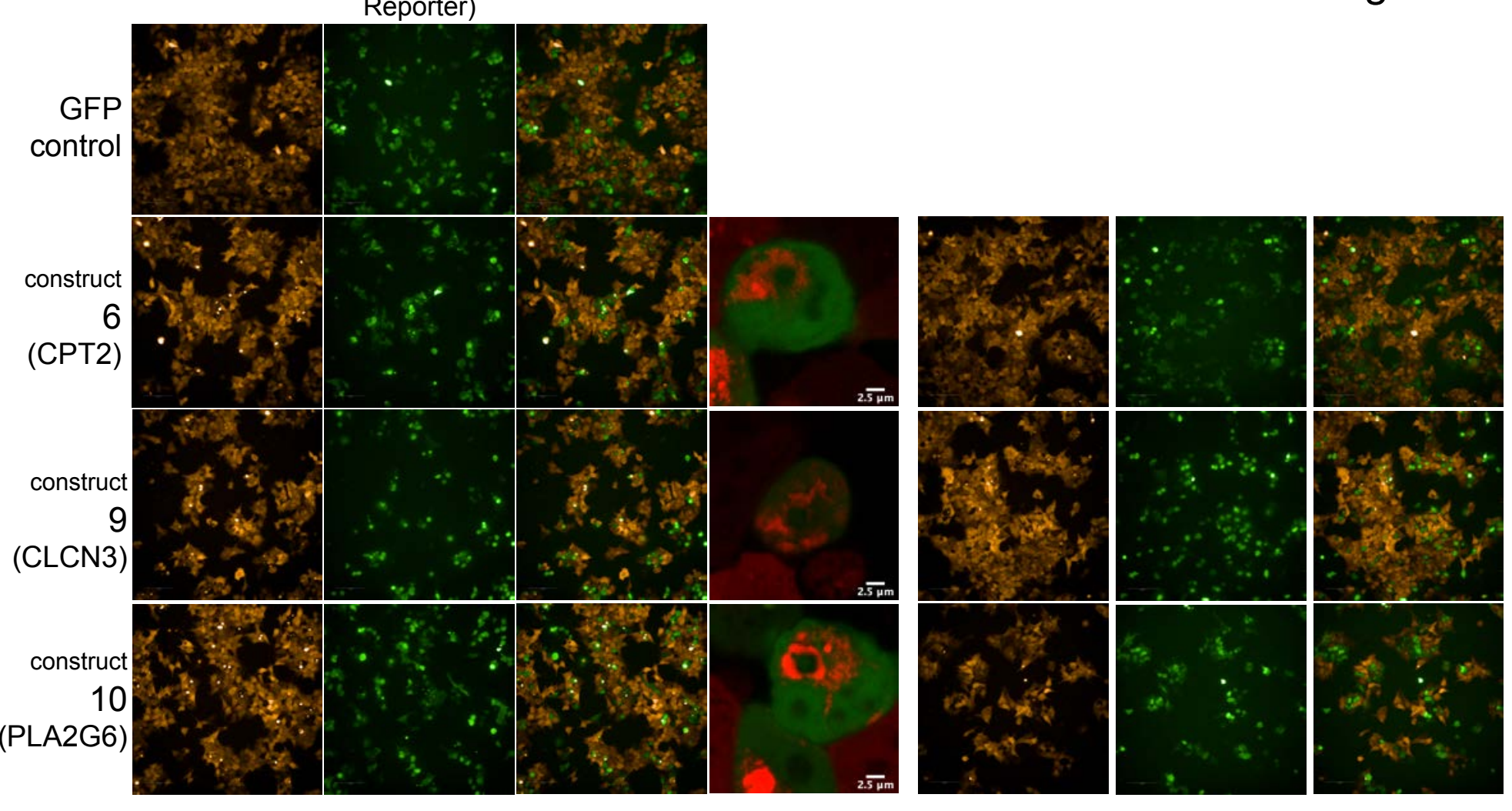

e

ב⿺
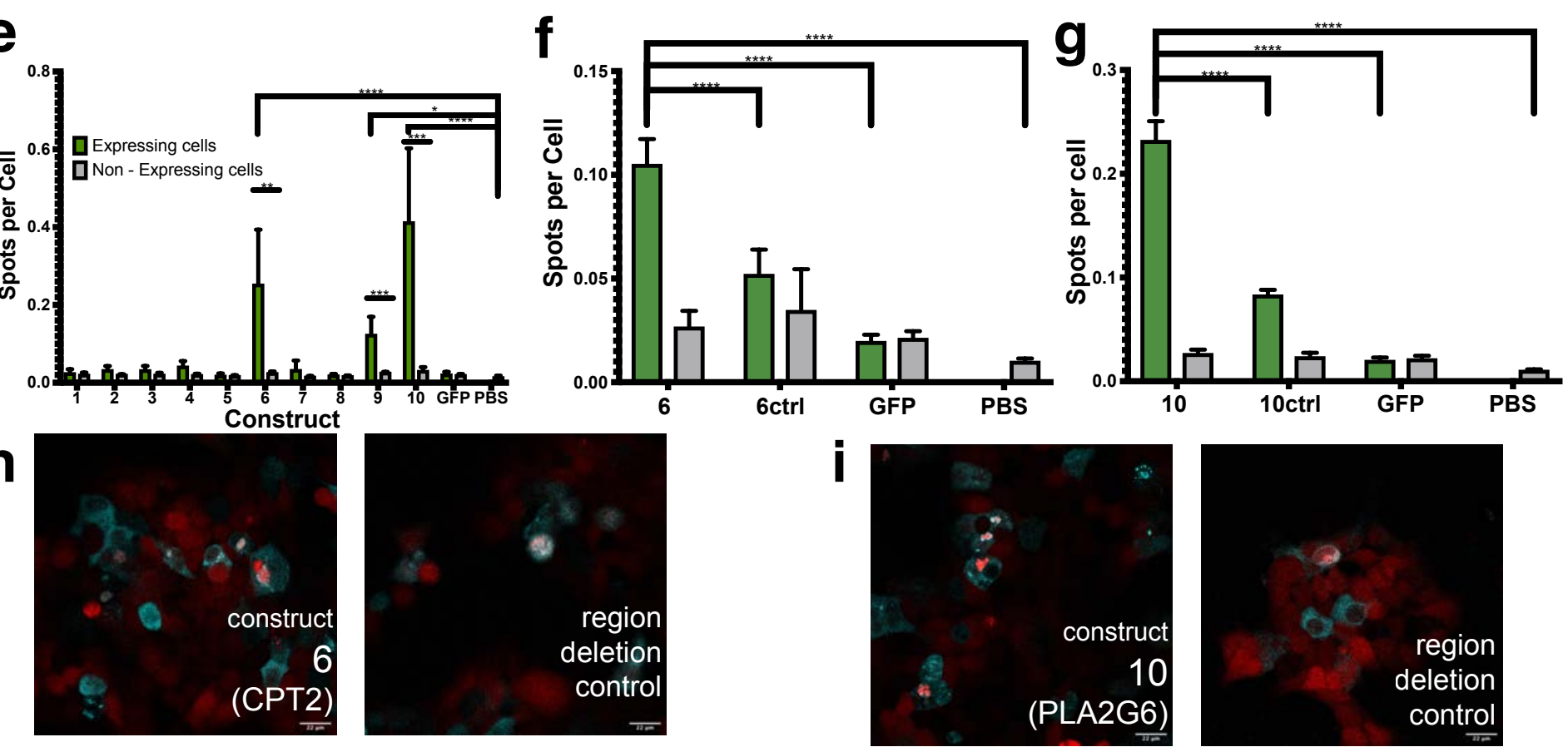

Konstantoulea, Guerreiro, et al - Figure 4 

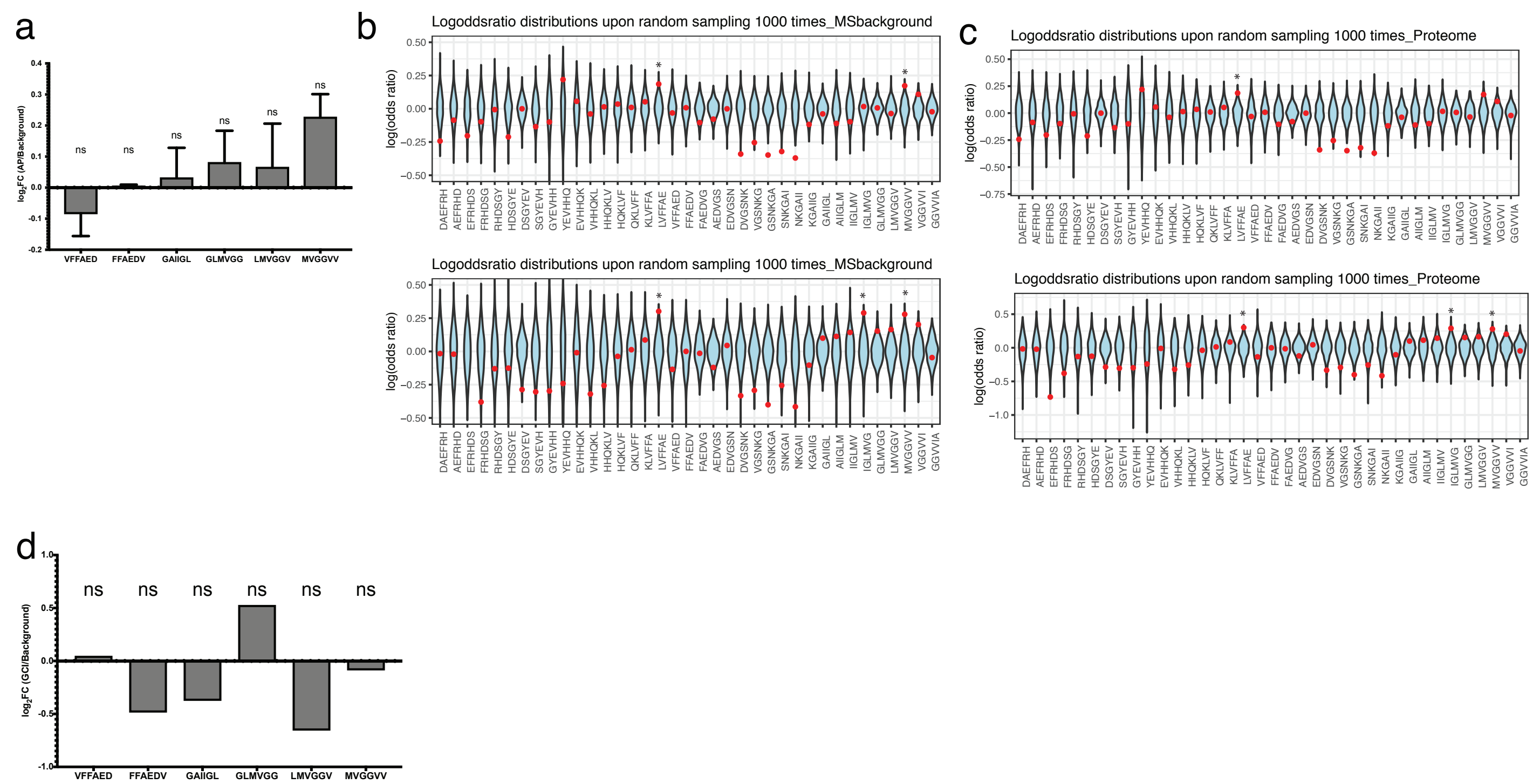
bioRxiv preprint do: https://doi.org/10.1101/2021.04.28.441786; this version posted April 30, 2021. The copyright holder for this preprint (which was not certified by peer review) is the author/funder, who has granted bioRxiv a license to display the preprint in perpetuity. It is made available under aCC-BY-NC-ND 4.0 International license.

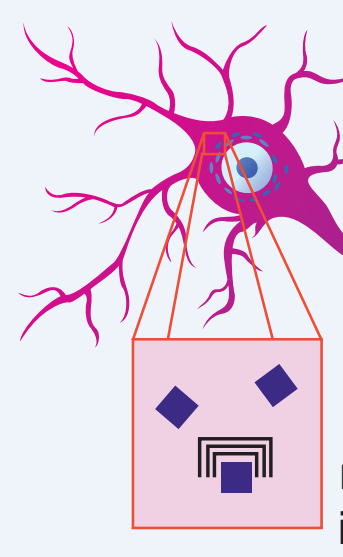

nucleating interaction A

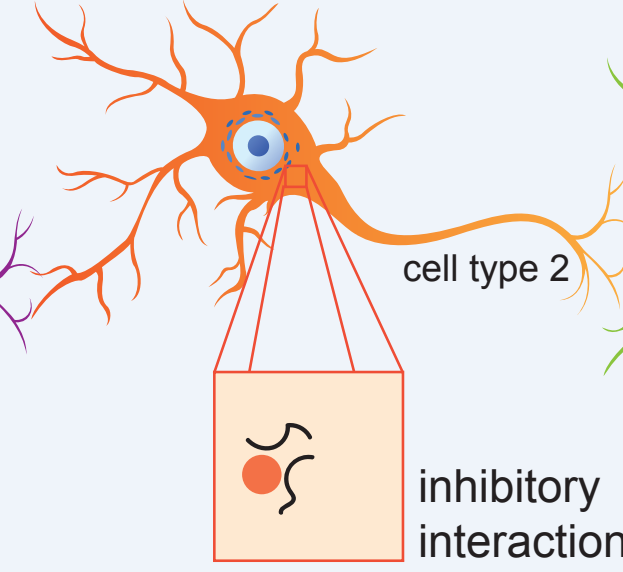
interaction

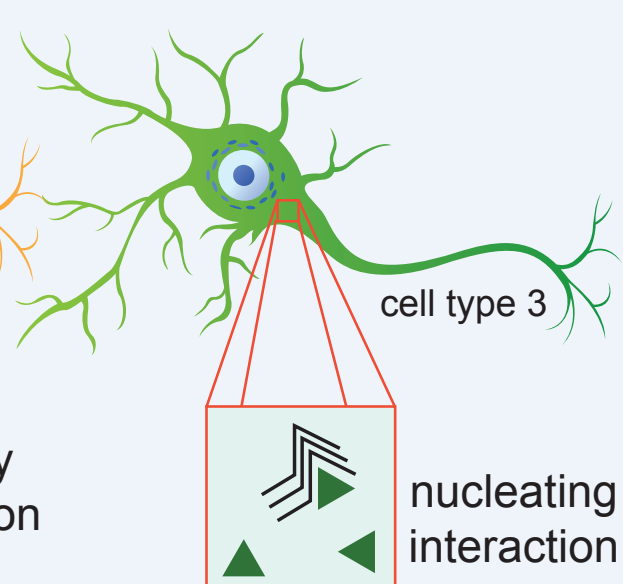

B

polymorph A

$\sim$

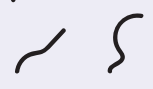

no aggregation
占

polymorph B 